\title{
Intercomparison of Evapotranspiration Over the Savannah Volta Basin in West Africa Using Remote Sensing Data
}

\author{
S. Opoku-Duah, D.N.M. Donoghue * and T. P. Burt \\ Department of Geography, Durham University, Science Site, Durham, DH1 3LE, UK \\ Tel 00-44-191-334-1867; Fax 00-191-334-1801; E-mails: stephen.opoku-duah@durham.ac.uk; \\ danny.donoghue@durham.ac.uk; t.p.burt@durham.ac.uk
}

* Author to whom correspondence should be addressed; E-mail: danny.donoghue@durham.ac.uk Received: 7 June 2007 / Accepted: 19 March 2008 / Published: 17 April 2008

\begin{abstract}
This paper compares evapotranspiration estimates from two complementary satellite sensors - NASA’s Moderate Resolution Imaging Spectroradiometer (MODIS) and ESA's ENVISAT Advanced Along-Track Scanning Radiometer (AATSR) over the savannah area of the Volta basin in West Africa. This was achieved through solving for evapotranspiration on the basis of the regional energy balance equation, which was computationally-driven by the Surface Energy Balance Algorithm for Land algorithm (SEBAL). The results showed that both sensors are potentially good sources of evapotranspiration estimates over large heterogeneous landscapes. The MODIS sensor measured daily evapotranspiration reasonably well with a strong spatial correlation $\left(R^{2}=0.71\right)$ with Landsat ETM+ but underperformed with deviations up to $\sim 2.0 \mathrm{~mm} \mathrm{day}^{-1}$, when compared with local eddy correlation observations and the Penman-Monteith method mainly because of scale mismatch. The AATSR sensor produced much poorer correlations $\left(R^{2}=0.13\right)$ with Landsat ETM+ and conventional ET methods also because of differences in atmospheric correction and sensor calibration over land.
\end{abstract}

Keywords: Remote Sensing, ET, MODIS, AATSR, Volta basin, West Africa, SEBAL 


\section{Introduction}

Understanding the spatial dynamics of evapotranspiration (ET) is critically important for food security and water resources management in Africa. With reference to the Volta basin (Fig 1), studies such as [1] and [2] have failed to estimate regional ET because of the sheer size of the area, surface heterogeneity and poor distribution of spatially referenced hydro-climatic data. For example, there are only five rainfall stations above Lake Volta and there are no ground-based energy flux towers. In this context, remote sensing is an attractive method for obtaining or modelling evaporative fluxes at the regional scale. NASA's Moderate Resolution Imaging Spectroradiometer (MODIS) and ESA's Environmental Satellite (ENVISAT) Advanced Along-Track Scanning Radiometer (AATSR) sensors present some of the most suitable sources of land surface information to help achieve this [3-5]. However, the quality of satellite data, the ease of application and availability of algorithms for retrieving key ET model parameters remains very important. In this context, it is necessary to evaluate the utility of different sensor data to ascertain their quality and value in terms of information sharing among scientific users, policy managers and data providers. This, in part, explains why the literature provides a range of studies that deal with regional synthesis of heat fluxes from previous satellites such as the NOAA Advanced Very High Resolution Radiometer (AVHRR) data [5, 6]. Recently, papers have also been published on ET intercomparison from MODIS and AVHRR sensors [4, 6, 7], and MODIS against the Environmental Satellite (ENVISAT) Medium Resolution Imaging Spectrometer (MERIS) [8]. More specifically, recent studies have demonstrated the advantage of MODIS over AVHRR, taking advantage of MODIS bands for land temperature detection and biomass estimation [6]. First, MODIS has narrower spectral bands at the visible and near infrared wavelengths (36 channels) than AVHRR, which enhances discrimination of vegetation properties [8]. Secondly, the MODIS sensor has one of the most accurate calibration subsystems. This allows the raw brightness values to be converted into true percentage reflectance or radiance measurements [9, 10]. Thirdly, MODIS has a higher radiometric resolution than AVHRR using 16 bits of quantization in all bands as opposed to AVHRR's 10 bits [8]. However, this is the first study to compare MODIS with AATSR. Specifically, the paper seeks to examine the relative potential of MODIS and AATSR for measuring key components of the energy balance equation such as surface temperature $\left(\mathrm{T}_{\mathrm{s}}\right)$ and ET over the Volta basin, which might potentially be used to predict regional water availability.

The paper is structured in the following way: the first part provides a description of the MODIS and AATSR sensor data, followed by their application to the study area. The second part describes the study methods including a stepwise description of image processing, derivation of key energy fluxes and sensor intercomparison. This section also deals with data evaluation using a $30 \mathrm{~m}$ resolution Landsat ETM+ image, ground data and published information. The third part discusses the results, which is followed by a summary of the key findings. 


\section{Materials and Methods}

\subsection{The Study Area}

The Tamale district (right-hand-side inset of Fig 1) was selected as the study area for three principal reasons: (1) the area is representative of the main land cover types in the Guinea savannah region; (2) the Tamale hydrometeorological monitoring station is a good source of historical data; and (3) the area is one of the most accessible for equipment installation and field data collection. The Volta basin encompasses six West African countries (Benin, Burkina Faso, La Côte d'Ivoire, Ghana and Mali boundaries shown in light grey in Fig 1) covering an area of about 400,000 km². Over 70 million of West Africans depend on the Volta for food and water resources, housing, energy in terms of hydropower supply, and lake transport. The need to understand fluctuations in the key energy processes that control water availability in the region is therefore of utmost importance.

Figure 1. Location of the Volta river basin in West Africa Source: Modified after GLOWA-Volta Project [11]. The Tamale White Volta catchment area $\left(5,311 \mathrm{~km}^{2}\right)$ is shown as an inset on the right-hand-side. The inset is a false colour composite Landsat ETM+ image dated 05/01/2004. The Red-Green-Blue colours represent ETM+ bands 4, 3, 2. The study area encompasses parts of the Tamale, Yendi and Salaga districts of Ghana.
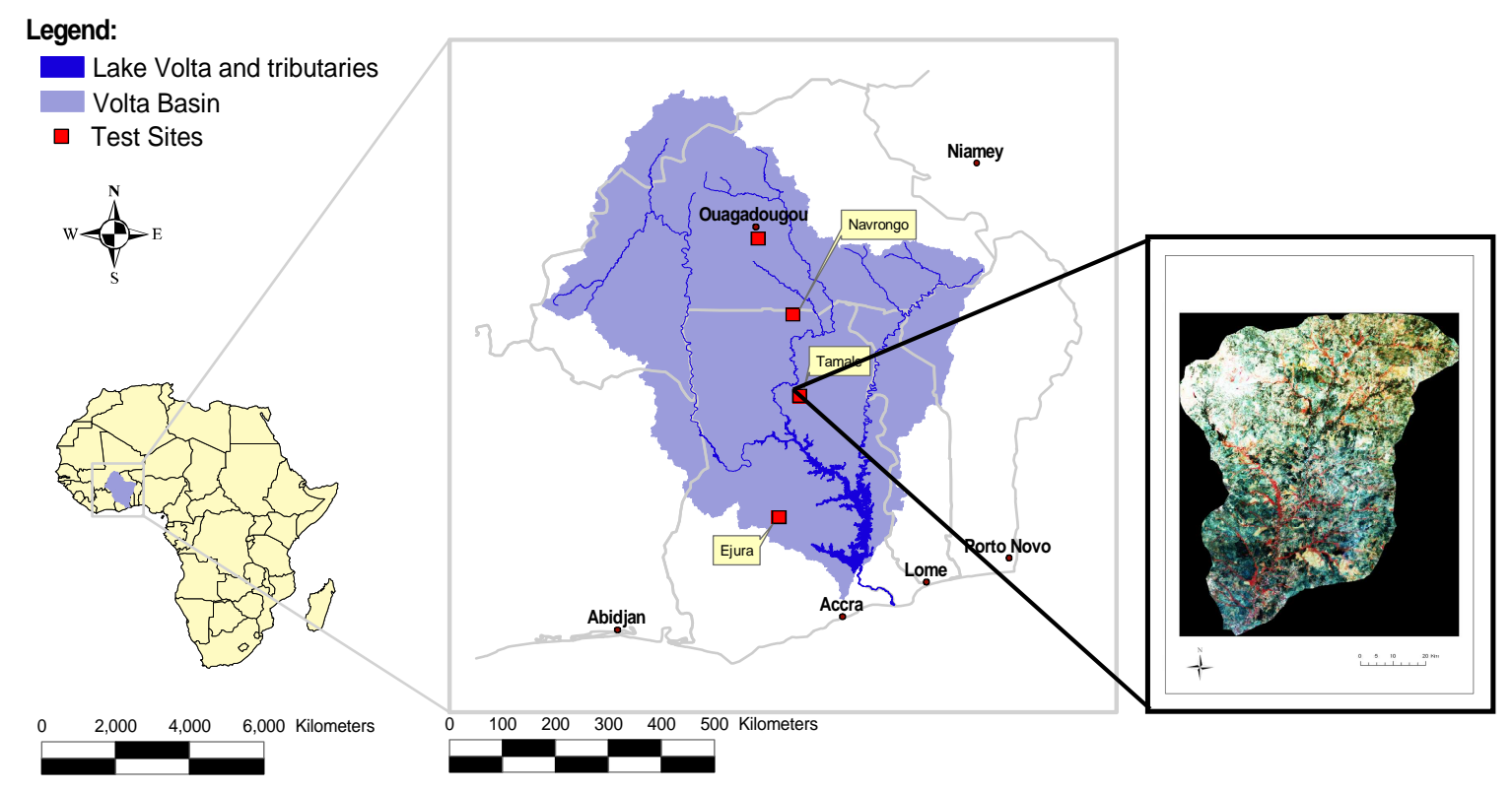

The climate of tropical West Africa is largely influenced by the movement of the Inter-Tropical Convergence Zone (ITCZ), which is an area of low pressure cells, where the Northeast Trade Winds meet the Southeast Trade Winds near the Earth's equator [12]. As these winds converge, moist air is forced upward causing water vapour to condense, and as the air cools and rises a band of heavy precipitation results. West Africa is also characterised by high daily/annual temperatures (see Table 1), which are closely related to the region's position in terms of the Equator, Gulf of Guinea and Sahara desert. Table 1 is important for two reasons: (1) it provides general long-term climatic information about West Africa, and (2) it places the study area and subsequent discussion into a regional context. 
West Africa is largely drained by three transboundary river systems - the Niger, Senegal and Volta. The Volta Lake $\left(\sim 8,500 \mathrm{~km}^{2}\right)$ developed from the Volta River (see Fig1), forms a massive inland drainage and flow regulating system, whose hydrological conditions are central to the region's economy. The geology of the area is often valued in terms of rich mineral resources, but shallow aquifers also contribute significantly to the rural economy in terms of surface flow discharge and borehole water supply, particularly during the dry season [13]. Although a regional background is given here, it needs to be stressed the current data (Section 2.2) and subsequent discussion focuses on the Volta basin.

Table 1. Climatic conditions of West Africa.

\begin{tabular}{|c|c|c|c|c|c|c|c|c|}
\hline \multirow{2}{*}{$\begin{array}{l}\text { Data } \\
\text { Monitoring } \\
\text { Station }\end{array}$} & \multicolumn{2}{|c|}{ Geographical location } & \multirow[t]{2}{*}{ Country } & \multirow{2}{*}{$\begin{array}{l}\text { Ecological } \\
\text { zone }\end{array}$} & \multirow{2}{*}{$\begin{array}{l}\text { Mean } \\
\text { annual } \\
\text { rainfall } \\
(\mathbf{m m})\end{array}$} & \multirow{2}{*}{$\begin{array}{l}\text { Mean } \\
\text { annual } \\
\text { evapotran- } \\
\text { spiration } \\
(\mathbf{m m})\end{array}$} & \multirow{2}{*}{$\begin{array}{l}\text { Mean } \\
\text { annual } \\
\text { temp. } \\
\left({ }^{0} \mathrm{C}\right)\end{array}$} & \multirow{2}{*}{$\begin{array}{l}\text { Period of } \\
\text { climate } \\
\text { records }\end{array}$} \\
\hline & Lat. & Lon. & & & & & & \\
\hline Niamey & $13^{0} 48^{\prime} \mathrm{N}$ & $2^{0} 16^{\prime} \mathrm{W}$ & Niger & $\begin{array}{l}\text { Sahel } \\
\text { savannah }\end{array}$ & 560 & 2000 & 36.0 & $1905-1989$ \\
\hline Koro & $12^{0} 46^{\prime} \mathrm{N}$ & $7^{0} 49^{\prime} \mathrm{W}$ & Mali & $\begin{array}{l}\text { Sahel } \\
\text { savannah }\end{array}$ & 522 & 2041 & 36.8 & $1971-1990$ \\
\hline $\begin{array}{l}\text { Bobo } \\
\text { Dioulasso }\end{array}$ & $11^{0} 16^{\prime} \mathrm{N}$ & $4^{0} 31^{\prime} \mathrm{W}$ & $\begin{array}{l}\text { Burkina } \\
\text { Faso }\end{array}$ & $\begin{array}{l}\text { Sudan } \\
\text { savannah }\end{array}$ & 759 & 1958 & 31.5 & $1971-2000$ \\
\hline Tamale & $9^{0} 25, \mathrm{~N}$ & $0^{0} 50^{\prime} \mathrm{W}$ & Ghana & $\begin{array}{l}\text { Guinea } \\
\text { savannah }\end{array}$ & 1087 & 1650 & 28.2 & $1961-2000$ \\
\hline Axim & $5^{0} 09^{\prime} \mathrm{N}$ & $2^{0} 57^{\prime} \mathrm{W}$ & Ghana & Forest & 2148 & 1315 & 25.8 & $1961-2000$ \\
\hline
\end{tabular}

Sources: Modified after [14]; http://www.climate-zone.com/. Note: The study area is highlighted.

\subsection{Data Sources}

Landsat ETM+ (NOAA/NASA), Level 1B MODIS (NASA) and AATSR (ESA) imagery (Table 2) were used as the main sources of remotely sensed data [15]. For spatial validation of the MODIS and AATSR data, a single Landsat ETM+ (30m resolution) was required. However, cloud-free Landsat ETM+ data coincidental with the coarse-resolution data were unavailable. As a result, an image (Landsat ETM+) acquired on $5^{\text {th }}$ January 2004 was used as proxy data (Table 2). Although the Level 1B products do not directly contain images, they still contain calibrated data which are often used by other software applications to construct the images. Aside from satellite data, a 40-year (19612000) record of daily air temperatures as a well as historical (1970-1980) daily wind speed and sunshine data observed from the Tamale meteorological monitoring station served as key reference and ET modelling input data [14]. Unfortunately, spatially observed surface temperature $\left(T_{s}\right)$ data were not available for the study area. Indeed, data scarcity is a widely recognised problem in Africa and remains a major disincentive to regional-based studies [1-3; 15]. In this case, a number of assumptions were made in Section 2.3 to be able to operate the SEBAL algorithm. An important data set which was used 
to initialize and validate the SEBAL algorithm was energy flux (eddy correlation) data (Fig 2) measured for the Tamale district, courtesy of the GLOWA-Volta Project [11]. Additional sources of model input and validation data included field surface temperatures, which were observed from thermal data loggers at the time of satellite overpass (Table 3). The thermal loggers named A-E were installed in the study area as follows: north-western (urban), north-eastern (grassland bush), central (agriculture), eastern (open woodland) and southern (closed woodland) locations of the study area, with actual geographical coordinates shown in Table $3 b$.

Table 2. Characteristics of AATSR and MODIS data used for the study

\begin{tabular}{|c|c|c|c|c|c|c|}
\hline \multirow[t]{2}{*}{ Image Date } & \multirow[t]{2}{*}{ Satellite overpass (UTC) } & \multirow[t]{2}{*}{ Orbit } & \multirow[t]{2}{*}{ Track } & \multirow[t]{2}{*}{ Frame } & \multicolumn{2}{|c|}{ Central coordinates } \\
\hline & & & & & Lat & Lon \\
\hline \multicolumn{7}{|c|}{ AATSR Sensor } \\
\hline 040103 & $10: 13: 07-10: 14: 43$ & 4441 & 380 & 3500 & $9^{0} 51^{\prime} \mathrm{N}$ & $1^{0} 58^{\prime} \mathrm{W}$ \\
\hline 131104 & 10:04:47 - 10:06:23 & 14146 & 65 & 3500 & $9^{0} 18^{\prime} \mathrm{N}$ & $0^{0} 04 \mathrm{E}$ \\
\hline 021204 & 10:07:35 - 10:09:11 & 14418 & 337 & 3500 & $9^{0} 36^{\prime} \mathrm{N}$ & $0^{0} 35^{\prime} \mathrm{W}$ \\
\hline 181204 & $10: 04: 44-10: 06: 20$ & 14647 & 65 & 3500 & $9^{0} 19^{\prime} \mathrm{N}$ & $0^{0} 04^{\prime} \mathrm{E}$ \\
\hline 250105 & 10:10:25 - 10:12:01 & 15191 & 108 & 3500 & $9^{0} 37^{\prime} \mathrm{N}$ & $1^{0} 18^{\prime} \mathrm{W}$ \\
\hline \multicolumn{7}{|c|}{ MODIS Sensor } \\
\hline 040103 & $10: 25: 00-10: 30: 00$ & 16209 & - & - & $9^{0} 51^{\prime} \mathrm{N}$ & $01^{0} 58^{\prime} \mathrm{W}$ \\
\hline 131104 & 10:30:00 - 10:35:00 & 26097 & - & - & $3^{0} 54^{\prime} \mathrm{N}$ & $00^{0} 53^{0} \mathrm{E}$ \\
\hline 021204 & 11:00:00 - 11:05:00 & 26374 & - & - & $6^{0} 83^{\prime} \mathrm{N}$ & $07^{0} 51^{0} \mathrm{E}$ \\
\hline 181204 & 11:00:00 - 11:00:00 & 26607 & - & - & $7^{0} 91^{\prime} \mathrm{N}$ & $07^{0} 32^{0} \mathrm{E}$ \\
\hline 250105 & $10: 25: 00$ - 10:30:00 & 27160 & - & - & $9^{0} 37^{\prime} \mathrm{N}$ & $01^{0} 18^{\prime} \mathrm{W}$ \\
\hline \multicolumn{7}{|c|}{ Landsat ETM+ } \\
\hline 050104 & $10: 40: 00-10: 41: 00$ & - & 194 & 53 & $10^{0} 06^{\prime} \mathrm{N}$ & $00^{0} 36^{\prime} \mathrm{W}$ \\
\hline
\end{tabular}

Note: The Landsat ETM+ scene acquired on $5^{\text {th }}$ January 2004 was used mainly because of the absence of cloud-free data coincidental with the MODIS and AATSR overpass.

For regional-scale studies, the MODIS and AATSR sensors provide high quality spectral products with good radiometric and geometric properties. As indicated above, the MODIS sensor has a number of advantages including (36) multi-spectral channels (bands), which enable precise discrimination of vegetation types [4-8] and a daily revisit capability, which provides high data temporal frequency. Most of the MODIS data products are also freely available to users from the USGS website. The AATSR sensor has a number of particular capabilities. For example, it delivers data from both the reflectance and thermal infrared bands, which provides useful land-based parameters (e.g. land-cover and surface temperatures) often needed as key inputs to energy and water balance models. In terms of temperature mapping, the AATSR scenes are supplied to users as a ready source of brightness temperatures [7]. This is extremely valuable because data re-calibration problems which are often associated with the AVHRR and MODIS sensors are easily avoided. Furthermore, the spectral bands and spatial resolution $(1 \mathrm{~km})$ are quite similar to MODIS, which makes sensor inter-comparison 
possible [5, 6, 16, 17]. It is also worth noting that the digital data format of both the MODIS and AATSR provides capabilities which easily lend them for integration with new-generation GIS-based data assimilation schemes $[18,19]$. Table 4 displays the general characteristics of the satellite data sets used.

Figure 2. Local energy flux observations from the Dutch-type scintillometer instrument, which measures turbulent intensity fluctuations of the refractive index of air. Source: Reproduced from field data retrieved from the GLOWA-Volta database [11].

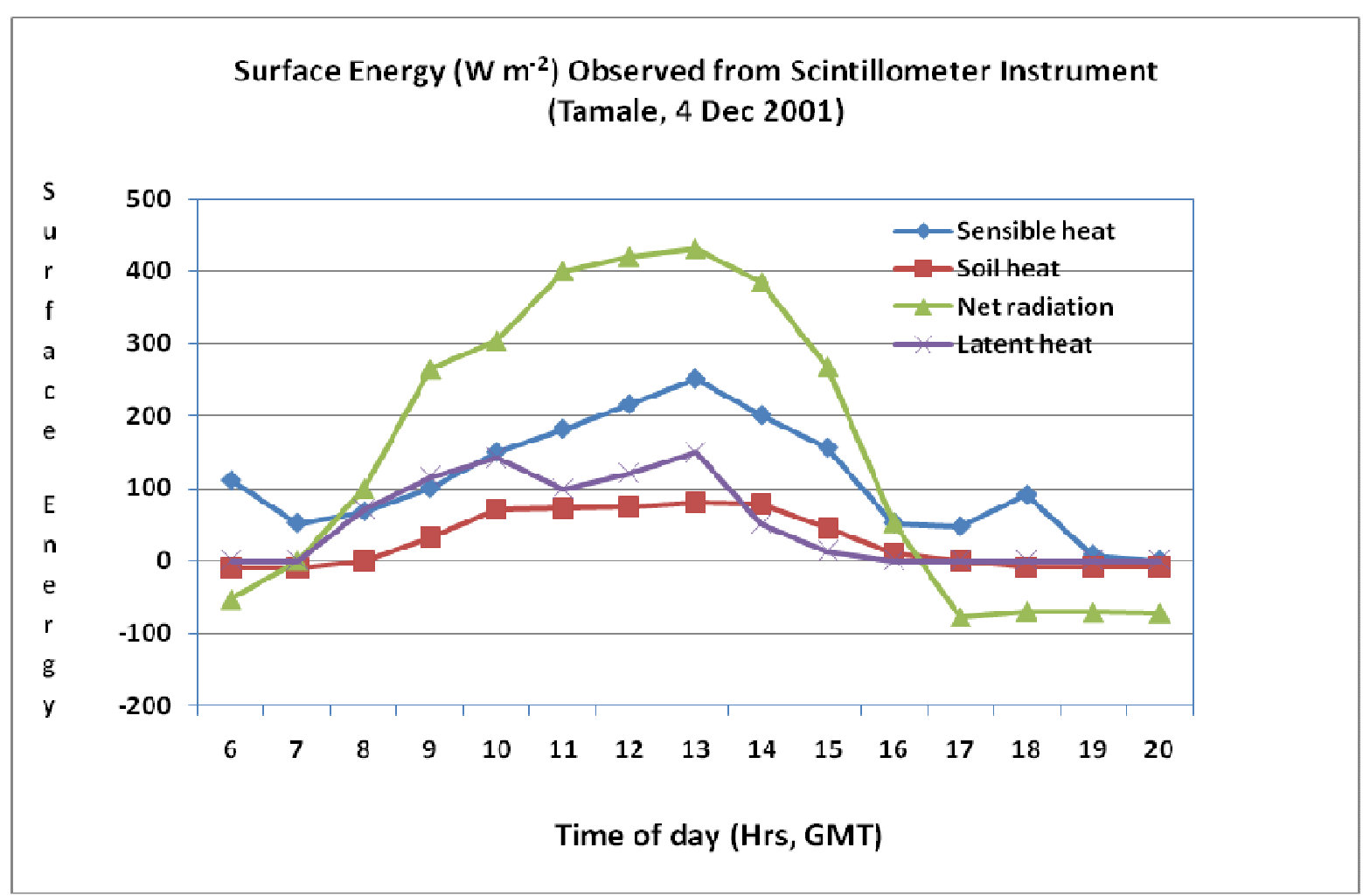

Table 3a. Soil temperatures (K) observed from thermal data logger at the time of MODIS \& AATSR overpass.

\begin{tabular}{|c|c|c|c|c|c|}
\hline & Logger A & Logger B & Logger C & Logger D & Logger E \\
\hline \multicolumn{6}{|l|}{ Date: 131104} \\
\hline Time 10:12 & 309.19 & 310.21 & 309.19 & 308.72 & 307.58 \\
\hline 10.32 & 309.27 & 310.32 & 309.97 & 308.86 & 307.97 \\
\hline 11:12 & 309.27 & 310.29 & 309.92 & 308.45 & 308.49 \\
\hline Av. Temp (K) & 309.24 & 310.29 & 309.69 & 308.68 & 307.95 \\
\hline \multicolumn{6}{|l|}{ Date: 021204} \\
\hline Time 10:12 & 312.67 & 312.08 & 312.39 & 308.11 & 307.88 \\
\hline 10.32 & 312.98 & 312.21 & 312.33 & 308.07 & 307.70 \\
\hline $11: 12$ & 312.98 & 312.29 & 312.38 & 308.64 & 308.66 \\
\hline Av. Temp (K) & 312.88 & 312.19 & 312.37 & 308.27 & 308.08 \\
\hline
\end{tabular}

The locations of the thermal loggers named here as A-E are given in Table $3 \mathrm{~b}$ 
Table 3b. Geographical locations of the thermal loggers.

\begin{tabular}{|l|l|l|l|l|}
\hline & $\begin{array}{l}\text { Geographical } \\
\text { description (see } \\
\text { Fig 2) }\end{array}$ & Latitude $\left({ }^{0} \mathrm{~N}\right)$ & Longitude $\left({ }^{0} \mathrm{~W}\right)$ & Land cover class \\
\hline Logger A & North-west & $09^{0} 26^{\prime}$ & $00^{0} 51^{\prime}$ & Urban \\
\hline Logger B & North-east & $09^{0} 28^{\prime}$ & $00^{0} 26^{\prime}$ & Grassland-bush \\
\hline Logger C & Central & $09^{0} 14^{\prime}$ & $00^{0} 37^{\prime}$ & Agriculture \\
\hline Logger D & East & $09^{0} 04^{\prime}$ & $00^{0} 28^{\prime}$ & Open Woodland \\
\hline Logger E & South & $08^{0} 56^{\prime}$ & $00^{0} 50^{\prime}$ & Closed Woodland \\
\hline
\end{tabular}

The thermal loggers were installed in the Tamale study area only (see Fig 1)

Table 4. Technical characteristics of key sensor data sets applied in this study.

\begin{tabular}{|c|c|c|c|c|c|}
\hline \multirow{2}{*}{$\begin{array}{l}\text { Data } \\
\text { source }\end{array}$} & \multirow{2}{*}{$\begin{array}{l}\text { Spatial } \\
\text { resolution } \\
\text { (m) }\end{array}$} & \multicolumn{4}{|c|}{ Spectral range $(\mu \mathrm{m})$} \\
\hline & & $*$ VIS & NIR band & MIR band & TIR band \\
\hline $\begin{array}{l}\text { Landsat } \\
\text { ETM+ }\end{array}$ & $\begin{array}{l}30(15 \mathrm{~m} \text { for } \\
\text { panchromatic } \\
\text { and } 60 \mathrm{~m} \text { for } \\
\text { thermal band })\end{array}$ & $\begin{array}{l}\text { Band1 }(0.45-0.52) \\
\text { Band2 (0.52-0.60) } \\
\text { Band3 (0.63-0.69) } \\
\text { Pan }(0.5-0.90)\end{array}$ & Band4 (0.76-0.90) & $\begin{array}{l}\text { Band5 (1.55- } \\
1.75) \\
\text { Band7 (2.08- } \\
2.35)\end{array}$ & Band6 (10.4-12.50) \\
\hline $\begin{array}{l}\text { ENVISAT } \\
\text { AATSR } \\
\text { Level 1B }\end{array}$ & $1 \mathrm{~km}$ & $\begin{array}{l}\text { Band1 (0.545-0.565) } \\
\text { Band2 (0.649-0.669) }\end{array}$ & $\begin{array}{l}\text { Band3 } \\
(0.855-0.875)\end{array}$ & $\begin{array}{l}\text { Band4 } \\
(1.580-1.640)\end{array}$ & $\begin{array}{l}\text { Band5 (3.50-3.89) } \\
\text { Band6 (10.40-11.30) } \\
\text { Band7 (11.50-12.50) }\end{array}$ \\
\hline $\begin{array}{l}\text { MODIS } \\
\text { Level 1B }\end{array}$ & $\begin{array}{l}250(500 \mathrm{~m} \\
\text { for bands } 3-7) \\
\text { and } 1000 \mathrm{~m} \\
\text { for bands } \\
8-36)\end{array}$ & $\begin{array}{l}\text { Band1 }(0.62-0.670) \\
\text { Band3 }(0.46-0.48) \\
\text { Band4 }(0.55-0.57) \\
\text { Band8 }(0.41-0.42) \\
\text { Band9 }(0.44-0.45) \\
\text { Band10 (0.44-0.49) } \\
\text { Band11 (0.53-0.54) } \\
\text { Band12 (0.55-0.56) } \\
\text { Band13(0.66-0.67) } \\
\text { Band14 (0.67-0.68) }\end{array}$ & $\begin{array}{l}\text { Band2 }(0.84-0.87) \\
\text { Band5 }(1.23-2.50) \\
\text { Band15(0.74-0.75) } \\
\text { Band16(0.86-0.87) } \\
\text { Band17(0.89-0.92) } \\
\text { Band18(0.93-0.94) } \\
\text { Band19(0.91-0.96) }\end{array}$ & $\begin{array}{l}\text { Band6 } \\
(1.628-1.652) \\
\text { Band7 } \\
(2.105-2.155) \\
\text { Band26 } \\
(1.36-1.39)\end{array}$ & $\begin{array}{l}\text { Band20 (3.66-3.84) } \\
\text { Band21 (3.92-3.98) } \\
\text { Band22 (3.92-3.98) } \\
\text { Band23 (4.02-4.08) } \\
\text { Band24 (4.43-4.49) } \\
\text { Band25 (4.48-4.54) } \\
\text { Band31 (10.78-11.28) } \\
\text { Band32 (11.77-12.27) }\end{array}$ \\
\hline
\end{tabular}

Sources: Various - NASA and ESA websites e.g. http://daac.gsfc.nasa.gov; http://www.msct.ssai.biz; http://envisat.esa.int/instruments/. *VIS=Visible, NIR=Near Infrared, MIR=Middle Infrared \& TIR=Thermal Infrared band 


\subsection{Study Methods}

\subsubsection{Image Processing}

The main image processing steps are described as follows:

- The raw Level 1B AATSR images (Table 2) were first read using the Windows version of the European Space Agency (ESA) Basic ERS \& ENVISAT AATSR and MERIS software (BEAM) (http://www.brockmann-consult.de/beam/). The BEAM is a collection of executable tools and an application programming interface which have been developed to facilitate the utilisation, viewing and processing of ENVISAT data products. It is particularly useful for importing image data, visual interpretation, image geo-referencing, band arithmetic and image statistics.

- Brightness temperatures at the top of atmosphere $\left(\mathrm{T}_{\mathrm{B}}\right)$ were directly retrieved after running the BEAM software; the software automatically implements an inverted version of the Planck's equation where image radiances are converted to $T_{B}$ (see equation 1). The $T_{B}$ files were then exported and stored as GeoTIFF for further use.

- The raw Level 1B MODIS data (Table 2) were also read using NASA's HDF-EOS to GIS (HEG) conversion toolbox (http://eosweb.1arc.nasa.gov/PRODOCS/misr/geotiff_tool.html). The HEG software is useful for image viewing, geo-referencing to standard projections such as UTM and data conversion to GeoTIFF.

- Examination of the MODIS header files enabled the retrieval of calibration constants from the reflectance (Bands 1 and 2) and radiance (Bands 31 and 32) files of the composite product. The reflectance and radiance values were then used as appropriate to calculate calibrated versions of time series data following NASA's re-calibration procedures described in the MODIS L1B Product User's Guide [16]. The inverted Planck's equation was then applied to convert the image radiances ( $\mathrm{L}$ ) of each of the thermal infrared bands (TIR) to $\mathrm{T}_{\mathrm{B}}$ following the approach of [20] (equation 1) and later used as model inputs for calculating $\mathrm{T}_{\mathrm{s}}$.

$$
T_{B}=\frac{c_{2}}{\lambda \ln \left[\frac{c_{1}}{\lambda^{5} L}+1\right]}
$$

where $c_{1}=3.74 * 10^{8}$ and $c_{2}=1.439 * 10^{4}$ and $\lambda=$ average wavelength of the TIR bands; represented as bands 31 and 32 for MODIS and 6 for Landsat ETM+ (see Table 4). $\mathrm{T}_{\mathrm{B}}$ was used at a later stage to calculate $\mathrm{T}_{\mathrm{s}}$ in the next section.

- To solve for equation 1 an ERDAS-Imagine based algorithm was applied for both the Landsat ETM+ scene ( $5^{\text {th }}$ January 2004) and the MODIS time series data (Table 2).

- Further, ERDAS spatial modelling tools were used to calculate NDVI (normalized difference vegetation index) for the Landsat ETM+, MODIS and AATSR imagery using the equation below [21]:

$$
N D V I=\frac{N I R-R}{N I R+R}
$$


where $N I R$ and $R$ are light reflectance in the near infrared $b_{a}$ nd and the red bands of the electromagnetic spectrum, respectively.

\subsubsection{SEBAL Processing in MATLAB}

For the MODIS and AATSR data, the results of equations (1) and (2) were applied as key inputs to the Surface Energy Balance Algorithm for Land (SEBAL) code $[22,23]$ which was run through code written in MATLAB. For the single Landsat ETM+ image, it was quicker to derive ET using ERDAS/GIS-based spatial modelling tools. Another important reason is that the ERDAS approach is easily repeatable in developing countries where software facilities and the image processing skills of users are quite limited [8]. The other inputs to the SEBAL algorithm are described in Table 5 below. The theoretical basis of the SEBAL is that it solves the energy and radiation balance equations (equations $3 \& 4$ ) on per-pixel basis, from which ET may be derived as the residual term of the regional energy balance model at the time of satellite overpass following the scheme shown in Fig 3.

$$
E T=R_{n}-H-G_{0}
$$

where ET = latent heat flux (evaporation), $\mathrm{R}_{\mathrm{n}}=$ net radiation, $\mathrm{H}=$ sensible heat flux, and $\mathrm{G}_{0}=$ soil heat flux. The units for all the above parameters are $\mathrm{Wm}^{-2}$.

Figure 3. Schematic illustration of how evapotranspiration (ET) may be estimated from remotely sensed data. Source: Modified after [24].

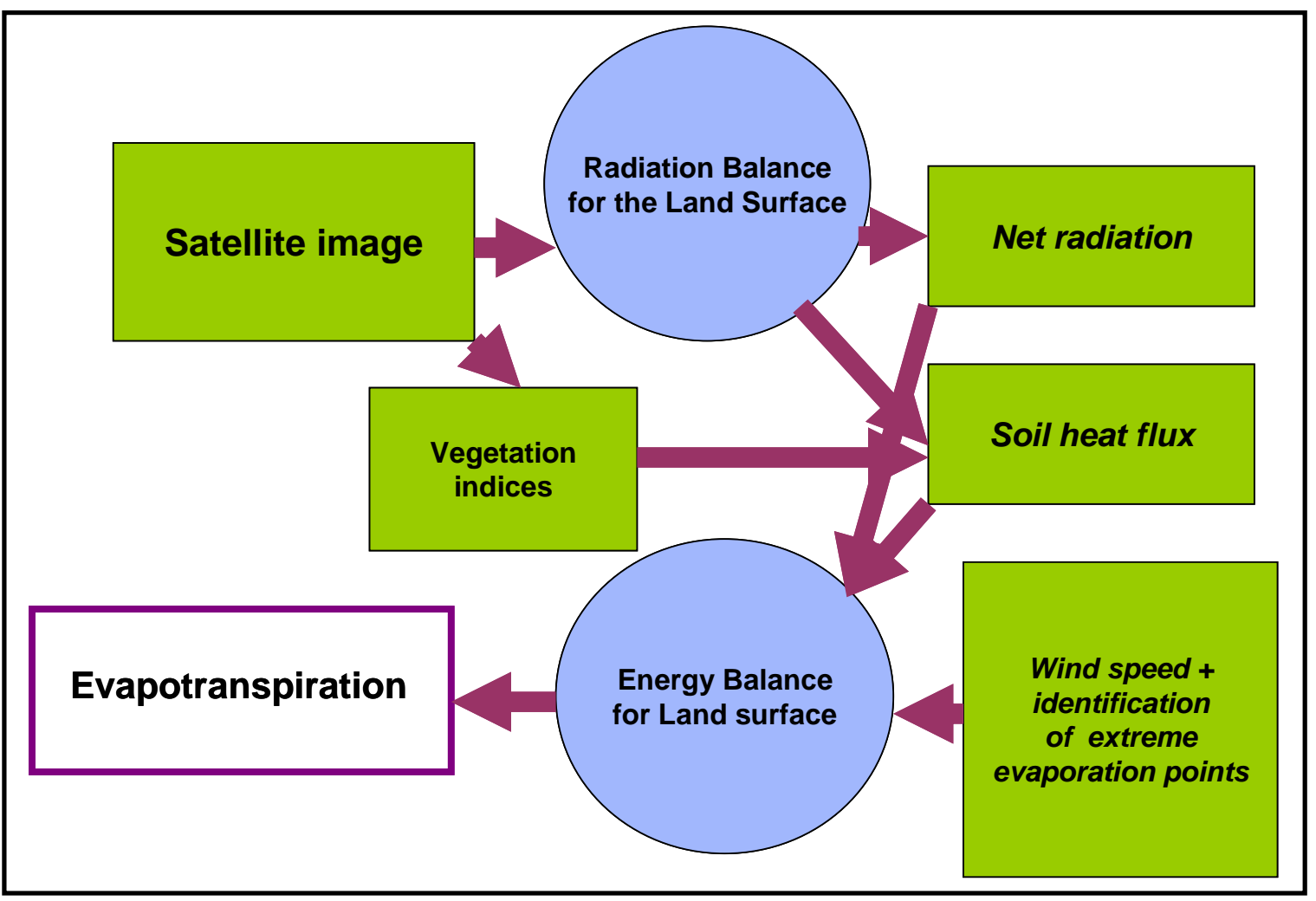


Table 5. Satellite and ground data used for regional-scale ET estimation and validation.

\begin{tabular}{|c|c|c|}
\hline \multicolumn{2}{|l|}{ Data Type } & Use of the Data \\
\hline \multirow[t]{2}{*}{$\begin{array}{l}\text { Satellite } \\
\text { data }\end{array}$} & $\begin{array}{l}\text { MODIS/AATSR } \\
\text { time series imagery }\end{array}$ & $\begin{array}{l}\text { The MODIS and AATSR provided the key instantaneous data needed } \\
\text { for energy and water balance modelling (net radiation, NDVI, BT) }\end{array}$ \\
\hline & $\begin{array}{l}\text { A Landsat ETM+ } \\
\text { scene acquired on } \\
5^{\text {th }} \text { January } 2004\end{array}$ & $\begin{array}{l}\text { The Landsat image also provided energy balance modelling data. In } \\
\text { addition, it was used for a detailed land use/cover classification and ET } \\
\text { maps for other purposes: (1) a guide for fieldwork; (2) to map wet and } \\
\text { evaporation points to guide SEBAL-based energy balance modelling; } \\
\text { and (3) as a source of validation for MODIS \& AATSR ET estimates }\end{array}$ \\
\hline $\begin{array}{l}\text { Satellite- } \\
\text { based } \\
\text { intermediate } \\
\text { parameters }\end{array}$ & $\begin{array}{l}\text { Brightness } \\
\text { temperatures }\left(\mathrm{T}_{\mathrm{B}}\right)\end{array}$ & $\begin{array}{l}T_{B} \text { was derived from satellite data. It served as the main intermediate } \\
\text { data for deriving } \mathrm{T}_{\mathrm{s}} \text { using the split-window algorithm [8] }\end{array}$ \\
\hline \multirow{3}{*}{$\begin{array}{l}\text { Local and } \\
\text { global } \\
\text { climate } \\
\text { records }\end{array}$} & $\begin{array}{l}\text { Radiation data and } \\
\text { constants (e.g. US } \\
\text { Navy website) }\end{array}$ & $\begin{array}{l}\text { Radiation constants e.g. sunshine duration }(n=12-14) \text { were used as input } \\
\text { data to: (1) validate satellite radiation measurements; and (2) up-scale } \\
\text { instantaneous to daily net radiation (see equation } 20) \text {. }\end{array}$ \\
\hline & $\begin{array}{l}\text { Local wind speed } \\
(u)\end{array}$ & $\begin{array}{l}\text { Wind speed was used as a source of momentum data for SEBAL-based } \\
\text { energy balance modelling }\end{array}$ \\
\hline & $\begin{array}{l}\text { Local air } \\
\text { temperature }\left(\mathrm{T}_{\mathrm{a}}\right)\end{array}$ & $\begin{array}{l}T_{a} \text { was used as a data source for the prediction of pixel-based } T_{a} \text { in } \\
\text { equation } 18 \text {. }\end{array}$ \\
\hline $\begin{array}{l}\text { Data from } \\
\text { fieldwork }\end{array}$ & $\begin{array}{l}\text { HOBO logger } \\
\text { temperatures }\end{array}$ & $\begin{array}{l}\text { Field temperatures were used as a source of SEBAL initialization and } \\
\text { validation data for satellite-based temperature estimates }\end{array}$ \\
\hline \multirow{2}{*}{$\begin{array}{l}E T \\
\text { validation } \\
\text { data }\end{array}$} & $\begin{array}{l}\text { GLOWA-Volta } \\
\text { field data }\end{array}$ & $\begin{array}{l}\text { The GLOWA data was used as one of the main sources validation for } \\
\text { satellite-derived net radiation and energy fluxes (e.g. ET) }\end{array}$ \\
\hline & $\begin{array}{l}\text { Penman-Monteith } \\
\text { estimates (Tamale } \\
\text { district) }\end{array}$ & $\begin{array}{l}\text { The Penman-Monteith estimates were used as additional source of } \\
\text { validation data for satellite-based ET }\end{array}$ \\
\hline
\end{tabular}

\section{Net Radiation $\left(R_{n}\right)$}

Following equation (3), the net radiation $\left(R_{n}\right)$, which is the amount of radiation left after all outgoing radiation $\left(\mathrm{L}^{\uparrow}\right)$ is subtracted from all incoming radiation $\left(\mathrm{L}_{\downarrow}\right)$, was calculated as follows:

$$
R_{n}=K_{\downarrow}(1-\alpha)+\left(L_{\downarrow}-L^{\uparrow}\right)
$$

where $\mathrm{K}_{\downarrow}=$ incoming shortwave radiation, $\alpha=$ albedo (dimensionless) and $\mathrm{L}_{\downarrow}$ and $\mathrm{L}^{\uparrow}$ are incoming and outgoing long wave radiation, respectively and the shortwave radiation $\left(\mathrm{Wm}^{-2}\right)$ reaching the Earth's surface under cloud-free conditions is calculated as:

$$
K_{\downarrow}=\tau \times K_{\downarrow}^{\text {toa }}
$$

where $\tau$ is atmospheric transmissivity and $\mathrm{K}_{\downarrow}^{\text {toa }}$ is the extraterrestrial solar radiation $\left(\mathrm{Wm}^{-2}\right)$. The extraterrestrial solar radiation at a given point in time is calculated according to the following relationship: 


$$
K_{\downarrow}^{\text {toa }}=G_{S C} E_{o}(\sin \delta \sin \phi+\cos \delta \cos \phi \cos \varpi)
$$

where $\mathrm{G}_{\mathrm{SC}}=$ solar constant $\left(1367 \mathrm{Wm}^{-2}\right), \mathrm{E}_{\mathrm{o}}=$ is eccentricity correction factor (i.e. average/actual Earth-sun distance, which ranges 0.980-0.989 [24; 25]), $\delta=$ solar declination, $\varnothing=$ latitude and $\omega=$ hour angle (all angles are in radians). Surface albedo $(\alpha)$ is calculable following an empirical formula derived by [26] as:

$$
\alpha=\frac{r_{p}-r_{a}}{\tau^{2}}
$$

where $r_{a}=$ albedo path radiance, $r_{p}=$ top-of-atmosphere radiance and $\tau^{2}=$ the two-way transmittance for solar radiation $\left(\mathrm{Wm}^{-2}\right)$. The surface albedo $(\alpha)$ of the darkest pixel (e.g. deep sea) is usually assumed to take a value of zero. If $\alpha=0$, it follows from equation 7 that $r_{a}=r_{p}$ of a deep sea and by approximation, the darkest pixel target. It has been shown that, for a known surface elevation $(z)$, the one way transmission $(\tau)$ may be predicted following an empirical relationship as [24]:

$$
\tau=0.75+2 \times 10^{-5} \times z
$$

Thus, assuming that the average elevation of the Tamale area is $180 \mathrm{~m}$, the two-way transmittance $\left(\tau^{2}\right)$ is approximately, 0.568. The above report has also shown that the fractional path radiance $\left(\mathrm{r}_{\mathrm{a}}\right)$ ranges from $0.025-0.04$. For tropical areas, a constant value of 0.03 has been suggested $24 ; 27]$. Further, the incoming long wave radiation $\left(\mathrm{Wm}^{-2}\right)$ is the downward thermal radiation flux from the atmosphere. It is computed using Stefan-Boltzmann equation as:

$$
L_{\downarrow}=\varepsilon_{a} \times \sigma \times T_{a}^{4}
$$

where $\varepsilon_{a}=$ atmospheric emissivity (dimensionless), $\sigma=$ Stefan-Boltzmann's constant $\left(5.67 \times 10^{-8} \mathrm{Wm}^{-2}\right.$ $\mathrm{K}^{-4}$ ) and $T_{a}=$ near surface temperature $(\mathrm{K})$ from climate records [14], which for lack of spatiallyobserved estimates, was first assumed to be invariant for each pixel, but later predicted from equation $18 ; \varepsilon_{a}$ may be calculated using an empirical model following as follows [27]:

$$
\varepsilon_{a}=0.85 \times(-\ln \tau)^{0.09}
$$

The outgoing long wave radiation $\left(\mathrm{Wm}^{-2}\right)$ is the upward thermal radiation leaving the surface. It is calculated using the Stefan-Boltzmann equation as follows:

$$
L^{\uparrow}=\varepsilon_{0} \times \sigma \times T_{s}^{4}
$$

where $\varepsilon_{0}=$ surface emissivity (dimensionless), $\sigma=$ Stefan-Boltzmann's constant and $\mathrm{T}_{\mathrm{s}}=$ surface temperature $(\mathrm{K})$ which was first estimated as a crude spatial average from Table $3 \mathrm{~b}(304 \mathrm{~K})$, but later calculated on per-pixel basis from the split-window algorithm (equation 24). The emissivity of an object is the ratio of the energy radiated by that object at a given temperature to the energy radiated by a black body at the same temperature. Since the thermal radiation of the surface is observed in the thermal bands of satellite data, one can compute the surface temperature if the emissivity of the land surface is estimated. In SEBAL, surface emissivity may be estimated using NDVI and an empiricallydriven method [28]:

$$
\varepsilon_{0}=1.009+0.047 \ln (N D V I)
$$

where NDVI > 0; otherwise, emissivity is assumed to be zero (e.g. water). 


\section{Soil Heat Flux $\left(G_{0}\right)$}

The soil heat flux is the rate of heat storage in a soil as a result of temperature gradient between soil surface and the underlying topmost soil layers. The SEBAL uses an empirical relationship by [23] which attempts to estimate $\mathrm{G}_{0}$ as a function of NDVI, surface temperature and albedo as follows:

$$
G_{0}=R_{n}\left(\frac{T_{s}-273}{\alpha}\right)\left[0.0032 \times(1.1 \times \alpha)+0.0062 \times(1.1 \times \alpha)^{2}\right] \times\left(1-0.978 \times N D V I^{4}\right)
$$

\section{Sensible Heat Flux $(H)$}

Sensible heat flux is the rate at which energy is lost through convection and diffusion processes as a result of temperature difference between the surface and the lowest layers of the atmosphere:

$$
H=\frac{\rho_{a} \times C_{p} \times \Delta T}{r_{a h}}
$$

where $\rho=$ density of air $\left(\mathrm{Kg} \mathrm{m}^{-3}\right), \mathrm{c}_{\mathrm{p}}=$ air specific heat capacity $1013\left(\mathrm{JKg}^{-1} \mathrm{~K}^{-1}\right), \Delta \mathrm{T}=$ difference between surface and air temperature $\left({ }^{0} \mathrm{~K}\right)$ and $\mathrm{r}_{\text {rah }}=$ aerodynamic resistance for heat transport $\left(\mathrm{sm}^{-1}\right)$, determined by wind speed, surface roughness, displacement height and thermal instability of the atmosphere.

$$
r_{a h}=\frac{1}{k u^{*}}\left[\ln \left(\frac{z_{r e f}-d}{z_{o h}}\right)-\psi_{h}\right]
$$

and,

$$
u^{*}=\frac{k \times u_{\text {blend }}}{\left[\ln \left(\frac{z_{\text {blend }}-d}{z_{\text {om }}}\right)\right]-\psi_{m}}
$$

where $\mathrm{u}^{*}=$ friction velocity, $\mathrm{k}=$ von Karman's constant $(0.41), \mathrm{u}_{\text {blend }}=$ wind speed at the blending height (i.e. mixing layer), $\mathrm{z}_{\mathrm{blend}}=$ blending height, $\mathrm{z}_{\mathrm{oh}}=$ roughness length for heat transport, $\mathrm{z}_{\mathrm{om}}=$ roughness length for momentum transport, $\mathrm{d}=$ displacement height and $\psi_{\mathrm{h}}$ and $\psi_{\mathrm{m}}=$ are stability correction factors for heat and momentum transport, respectively. The temperature difference $(\Delta \mathrm{T})$ is predicted in order to estimate $\mathrm{H}$ from equation 14 following $[22,23]$ :

$$
\Delta T=\frac{H \times r_{a h}}{\rho_{a} \times C_{p}}
$$

In this equation, $\mathrm{H}$ and $\Delta \mathrm{T}$ are both unknown factors but are directly related to one another, as well as to the value of $r_{a h}$. Therefore, $\Delta \mathrm{T}$ is calculated at two extremes, "indicator pixels" (wettest and driest pixels) by assuming values for $H$ at these reference pixels. The wettest pixel is the pixel where $\mathrm{H} \sim 0$ (i.e. all the available energy $\left[\mathrm{R}_{\mathrm{n}}-\mathrm{G}_{0}\right]$ is converted $\lambda \mathrm{ET}$ or $\Delta \mathrm{T}$ becomes zero), and the driest pixel is where $\lambda \mathrm{ET} \sim 0$, so that $\mathrm{H}=\mathrm{R}_{\mathrm{n}}-\mathrm{G}_{0}$ or $\Delta \mathrm{T}$ is maximum. The wettest pixels are selected as pixels with high NDVI but with low temperature, while the driest pixels are selected as pixels with high temperature but with low NDVI and albedo. Subsequent to the selection of the wettest and driest pixels, the linear equation which gives value of $\Delta \mathrm{T}$ as a function of surface temperature is developed as:

$$
T_{s}-T_{a}=\Delta T=a+b \times T_{s}
$$


where $\mathrm{T}_{\mathrm{s}}=$ surface temperature, $\mathrm{T}_{\mathrm{a}}=$ air temperature (previously defined as near surface in equation 9), and $\boldsymbol{a} \& \boldsymbol{b}$ are constants. With the values of $\mathrm{T}_{\mathrm{s}}$ and $\Delta \mathrm{T}$ at the two pixels, $\boldsymbol{a} \& \boldsymbol{b}$ may then be solved iteratively, as $r_{a h}$ is also a function of $\mathrm{H}$, where $r_{a h}$ is calculated using equations 15 and 16 above. As noted before, lack of spatially-observed ground temperature data makes equation 18 relevant in the derivation of temperature difference $\left(\mathrm{T}_{\mathrm{s}}-\mathrm{T}_{\mathrm{a}}\right)$.

\section{Evapotranspiration (ET) Up-scaling Methods}

Under fair weather conditions, the evaporative fraction $(\Lambda)$, which is the ratio of latent heat flux to available energy, is generally assumed to be constant during daytime [23, 27]. Thus, $\Lambda$ may be used to integrate remotely sensed ET over the diurnal cycle as follows:

$$
\Lambda=\frac{\lambda E T}{\lambda E T+H}=\frac{\lambda E T}{R_{n}-G_{0}}
$$

where the instantaneous evaporative fraction $\left(\Lambda_{\text {ins }}\right)$ is equal to the integrated daily evaporative fraction $\left(\Lambda_{\text {day }}\right)$. Guided by the above principles, instantaneous net radiation may also be aggregated as daily net radiation $\left(\mathrm{R}_{\mathrm{n} \text {-day }}\right)$ following the approach by [23] as:

$$
R_{n-d a y}=(1-1.1 \times \alpha) \times K_{d a y}^{\downarrow}-110 \times \tau_{\text {day }}
$$

where $\tau_{\text {day }}=$ daily atmospheric transmissivity for radiation, which was calculated using the Angstrom formula as $\tau_{\text {day }}=0.25+0.5 \times \mathrm{n} / \mathrm{N}$, where $n=$ actual duration of sunshine and $\mathrm{N}=$ maximum possible sunshine or daylight hour. Cloud-free actual sunshine data (n) were obtained from the US Navy website - http://aa.usno.navy.mil. Daily incoming short wave radiation $\left(\mathrm{K}_{\text {day }}^{\downarrow}\right)$ was then calculated using the following relationship:

$$
K_{\text {day }}^{\downarrow}=11.5741 \times \tau_{\text {day }} \times K_{\downarrow-d a y}^{\text {toa }}
$$

where $K_{\downarrow-\text { day }}^{\text {toa }}=$ daily incoming short wave radiation at the top-of-atmosphere (TOA) was calculated using the sine method as:

$$
K_{\downarrow-d a y}^{\text {toa }}=\frac{24}{\pi} G_{S C} E_{o} \sin \delta \sin \phi\left[\frac{\pi}{180} \omega_{s}-\tan \omega_{s}\right]
$$

where $\omega_{\mathrm{s}}=$ sunset or sunrise hour angle (radians); the definition of the remaining parameters is given in equation 6. From equations 19 and 20, actual ET was set as a constant following [23] who used similar empirical models for the Sahel region in West Africa. Daily ET derived from equation 23 was validated using the GLOWA-Volta ground energy flux observations [11].

$$
E T_{\text {day }}=\frac{\Lambda \times R_{n-d a y}}{28.588}
$$

\section{Derivation of Land Surface Temperature $\left(T_{s}\right)$}

Following the split-window approach by [8], $\mathrm{T}_{\mathrm{S}}$ was estimated as:

$$
T_{s}=0.39 T_{1}^{2}+2.34 T_{1}-0.78 T_{1} \times T_{2}-1.34 T_{2}+0.39 T_{2}^{2}+0.56
$$

where $\mathrm{T}_{1}$ and $\mathrm{T}_{2}$ represent AATSR bands $6 \& 7$ and MODIS bands $31 \& 32$, respectively; and the coefficients are empirically determined on the basis of land cover types, vegetation fraction, season and time of day, atmospheric vapour pressure, satellite zenith angle and surface emissivity [7]. For the Landsat ETM+ data, $\mathrm{T}_{\mathrm{s}}$ was estimated using the single channel algorithm [31] and applying coefficients derived for the dry Roxo catchment in Portugal [27]. 


\section{Results and Discussion}

Sensor intercomparison studies can deliver several benefits, of which data quality assurance, provision of market information and sharing of technical information among key stakeholders are paramount. Nevertheless, several constraints remain crucial, such as lack of consensus about image pre-processing methods, differences in sensor footprints and occurrence of random errors including missing data [5 - 7]. Some of these issues are discussed in the subsequent section.

\subsection{Results}

\subsubsection{Sensor Intercomparison of $\mathrm{T}_{\mathrm{s}}$}

An important motivation for evaluating $\mathrm{T}_{\mathrm{s}}$ from different sensors is the close interaction between temperature, sensible and latent heat fluxes. At the catchment scale, dynamics of surface energy is a critical indicator of water availability, which in turn, constitutes very useful information for water resources management. For example, the operational management of the downstream Volta Lake for hydropower generation is of great economic importance. The results in Table 6 present the temporal variability of $\mathrm{T}_{\mathrm{s}}$ over the Tamale district derived from the Landsat ETM+, MODIS and AATSR sensors. The Tamale district is important for both economic and environmental reasons. As one of the largest urban areas in the Guinea savannah zone in Ghana, water scarcity is a severe problem. Secondly, the area is heterogeneous in terms of savannah land cover [18]. This explains the importance of understanding the energy dynamics of the area.

Table 6 shows that the average MODIS $\mathrm{T}_{\mathrm{s}}$ over the Tamale district was $309.9 \mathrm{~K}$ compared with $320.6 \mathrm{~K}$ by the AATSR instrument. Although the MODIS $\mathrm{T}_{\mathrm{s}}$ compares well with the Landsat sensor $(\sim 302 \mathrm{~K})$, the result is inconclusive without ground truth validation. This makes two types of validation necessary; first, evaluation of the image thermal calibration methods and the secondly, verification of the results from independent field data (see Table 3). As shown in Section 2.3.1, the data from both sensors were subjected to similar image processing methods, where image radiances were first converted to brightness temperature $\left(\mathrm{T}_{\mathrm{B}}\right)$ using the inverted Planck's equation and subsequent derivation of surface temperature $\left(\mathrm{T}_{\mathrm{S}}\right)$, using the split-window algorithm. The only difference is that the AATSR $T_{B}$ was obtained directly whereas the MODIS $T_{B}$ was calibrated manually [18]. The effect of this is examined in Table 7.

Table 7 shows that the average AATSR $T_{B}$ (full-scenes) are slightly higher than MODIS in the 11 and $12 \mu \mathrm{m}$ thermal bands (channels) at nadir viewing angles; the deviations in these channels being 5.1 and $4.7 \mathrm{~K}$, respectively. The difference between the coarse-resolution sensors (MODIS \& AATSR) and the reference Landsat ETM+ $\mathrm{T}_{\mathrm{B}}$ is even wider $(7-13 \mathrm{~K})$. Over a large area, the above $\mathrm{T}_{\mathrm{B}}$ variations are large [5, 7], which also closely reflect the magnitude of $T_{s}$ deviations in Table 6 . This tends to emphasize the previous opinion that the $T_{\mathrm{s}}$ deviations may not be due to differences produced from image processing, but variations in sensor and instrument characteristics. 
Table 6. Variation of surface temperature $\left(\mathrm{T}_{\mathrm{s}}\right)$, normalised difference vegetation indeed (NDVI) and daily evapotranspiration (ET) over the Volta savannah from MODIS \& AATSR sensors $(N=71$ pixels $)$.

\begin{tabular}{|c|c|c|c|c|c|c|c|}
\hline \multirow{2}{*}{$\begin{array}{l}\text { Date of image } \\
\text { acquisition } \\
\text { [Julian day] }\end{array}$} & \multirow{2}{*}{$\begin{array}{l}\text { Landsat } \\
\text { ETM+ } \\
050104 \\
{[05]}\end{array}$} & \multicolumn{3}{|c|}{ MODIS } & \multicolumn{3}{|c|}{ AATSR } \\
\hline & & $\begin{array}{l}131104 \\
{[318]}\end{array}$ & $\begin{array}{l}021204 \\
{[337]}\end{array}$ & $\begin{array}{l}250105 \\
{[25]}\end{array}$ & $\begin{array}{l}131104 \\
{[318]}\end{array}$ & $\begin{array}{l}021204 \\
{[337]}\end{array}$ & $\begin{array}{l}250105 \\
{[25]}\end{array}$ \\
\hline \multicolumn{8}{|c|}{ Land Surface Temperature $\left(T_{s}\right)$} \\
\hline Maximum & 312.451 & 309.476 & 309.650 & 310.390 & 317.037 & 323.089 & 322.356 \\
\hline Minimum & 286.318 & 302.078 & 302.616 & 306.691 & 308.623 & 308.750 & 312.347 \\
\hline Mean & 301.869 & 304.383 & 306.217 & 308.586 & 312.463 & 318.970 & 319.050 \\
\hline Std. Deviation & 7.091 & 1.594 & 1.999 & 0.965 & 1.871 & 2.890 & 1.882 \\
\hline \multicolumn{8}{|l|}{$N D V I$} \\
\hline Maximum & 0.809 & 0.727 & 0.720 & 0.661 & 0.751 & 0.701 & 0.693 \\
\hline Minimum & 0.025 & 0.387 & 0.326 & 0.312 & 0.519 & 0.461 & 0.488 \\
\hline Mean & 0.521 & 0.620 & 0.566 & 0.489 & 0.639 & 0.587 & 0.582 \\
\hline Std. Deviation & 0.083 & 0.066 & 0.079 & 0.068 & 0.045 & 0.074 & 0.046 \\
\hline \multicolumn{8}{|c|}{ Daily Evapotranspiration $\left(\boldsymbol{E T}_{24}\right)$} \\
\hline Maximum & 8.510 & 2.297 & 3.082 & 2.831 & 0.987 & 1.471 & 0.706 \\
\hline Minimum & 0.000 & 0.020 & 0.025 & 0.904 & 0.000 & 0.300 & 0.000 \\
\hline Mean & 3.102 & 0.918 & 1.469 & 2.052 & 0.283 & 0.965 & 0.170 \\
\hline Std. Deviation & 1.424 & 0.609 & 0.840 & 0.400 & 0.213 & 0.282 & 0.140 \\
\hline
\end{tabular}

In the second case, reference is made to Fig 5, which compares satellite derived $\mathrm{T}_{\mathrm{s}}$ with field soil temperatures observed at the time of the satellites overpass (10:00 - 12:00 noon). Fig 5 was derived by calculating the mean (diurnal) logger temperatures from Table $3 \mathrm{~b}$ and plotting them against the satellite measurements. It is not always easy to compare point data with spatially derived satellite measurements without making some assumptions [5]. The following assumptions were made: (1) surface temperatures do not vary significantly within $1 \mathrm{~km}$ pixels where satellite measurements are made; and (2) sensor geometric effects on the location of the thermal loggers are of minimal significance. Guided by ground control points (geographical coordinates), five nearest $\mathrm{T}_{\mathrm{s}}$ data points from MODIS and AATSR maps were extracted and compared with the ground truth data. In the case of the Landsat ETM+ thermal map, average $\mathrm{T}_{\mathrm{s}}$ values were extracted from 30x30 pixel windows, reference to existing ground control points and the coarse-resolution data. As expected, the MODIS sensor better predicted $\mathrm{T}_{\mathrm{S}}\left(R^{2}=0.73\right)$, compared with both the AATSR $\left(R^{2}=0.41\right)$ and Landsat ETM+ $\left(R^{2}=0.59\right)$ as shown in Fig 4. The detailed data analysis and error assessment are discussed in the subsequent section. 
Table 7. Temporal statistics of MODIS \& AATSR brightness temperatures $\left(\mathrm{T}_{\mathrm{B}}\right)$.

\begin{tabular}{|c|c|c|c|c|c|c|}
\hline \multirow{3}{*}{$\begin{array}{l}\text { Date of image } \\
\text { acquisition } \\
\text { [Julian day] }\end{array}$} & \multicolumn{6}{|c|}{ MODIS } \\
\hline & \multicolumn{2}{|c|}{$131104[318]$} & \multicolumn{2}{|c|}{021204 [337] } & \multicolumn{2}{|c|}{250105 [25] } \\
\hline & $11 \mu \mathrm{m}$ & $12 \mu \mathrm{m}$ & $11 \mu \mathrm{m}$ & $12 \mu \mathrm{m}$ & $11 \mu \mathrm{m}$ & $12 \mu \mathrm{m}$ \\
\hline Maximum & 301.8 & 299.3 & 303.2 & 301.6 & 309.1 & 306.3 \\
\hline Minimum & 281.4 & 289.8 & 291.6 & 294.3 & 298.0 & 299.9 \\
\hline Mean & 296.0 & 292.0 & 299.3 & 292.7 & 302.2 & 300.8 \\
\hline \multirow[t]{4}{*}{ Std. Deviation } & 1.231 & 1.032 & 0.853 & 1.110 & 1.543 & 1.276 \\
\hline & \multicolumn{6}{|c|}{ AATSR } \\
\hline & \multicolumn{2}{|c|}{131104 [318] } & \multicolumn{2}{|c|}{021204 [337] } & \multicolumn{2}{|c|}{$250105[25]$} \\
\hline & $11 \mu \mathrm{m}$ & $12 \mu \mathrm{m}$ & $11 \mu \mathrm{m}$ & $12 \mu \mathrm{m}$ & $11 \mu \mathrm{m}$ & $12 \mu \mathrm{m}$ \\
\hline Maximum & 303.2 & 297.6 & 314.8 & 312.2 & 317.7 & 313.3 \\
\hline Minimum & 292.6 & 289.2 & 299.6 & 298.4 & 307.7 & 302.8 \\
\hline Mean & 298.9 & 294.8 & 305.0 & 303.3 & 309.1 & 304.7 \\
\hline \multirow[t]{3}{*}{ Std. Deviation } & 1.055 & 0.807 & 2.276 & 2.078 & 1.441 & 1.511 \\
\hline & \multicolumn{2}{|c|}{ Landsat ETM+ $(10.4-12.5 \mu \mathrm{m}$} & & & & \\
\hline & \multicolumn{2}{|c|}{$050104[05]$} & & & & \\
\hline Maximum & \multicolumn{2}{|c|}{309.990} & & & & \\
\hline Minimum & \multicolumn{2}{|c|}{283.720} & & & & \\
\hline Mean & \multicolumn{2}{|c|}{293.719} & & & & \\
\hline Std. Deviation & \multicolumn{2}{|l|}{7.691} & & & & \\
\hline
\end{tabular}

\section{Sensor Intercomparison of NDVI}

From Table 6, the variations in NDVI (used here as surrogate for biomass density) are closely related to dynamics of thermal energy and therefore, transpiration processes. The temporal variation of MODIS NDVI portrays this more consistently than the AATSR, which is also exemplified by the wider range of the MODIS NDVI values ( 0.36) compared with AATSR ( 0.22). For medium resolution $(1 \times 1 \mathrm{~km})$ satellites, an NDVI difference of approximately 0.20 (Fig 5) may cover an extremely wide ground area, vegetation types and biomass volume, which reinforces the advantage of the MODIS visible bands for NDVI estimation compared with AATSR. 
Figure 4. Comparison between satellite and logger temperature observations. The logger temperatures were calculated as an average observation from 10:00-12:00 noon. To compare with the $1 \mathrm{~km}$ resolution MODIS and AATSR data, the Landsat temperatures were extracted as average values from 30x30 pixel windows.
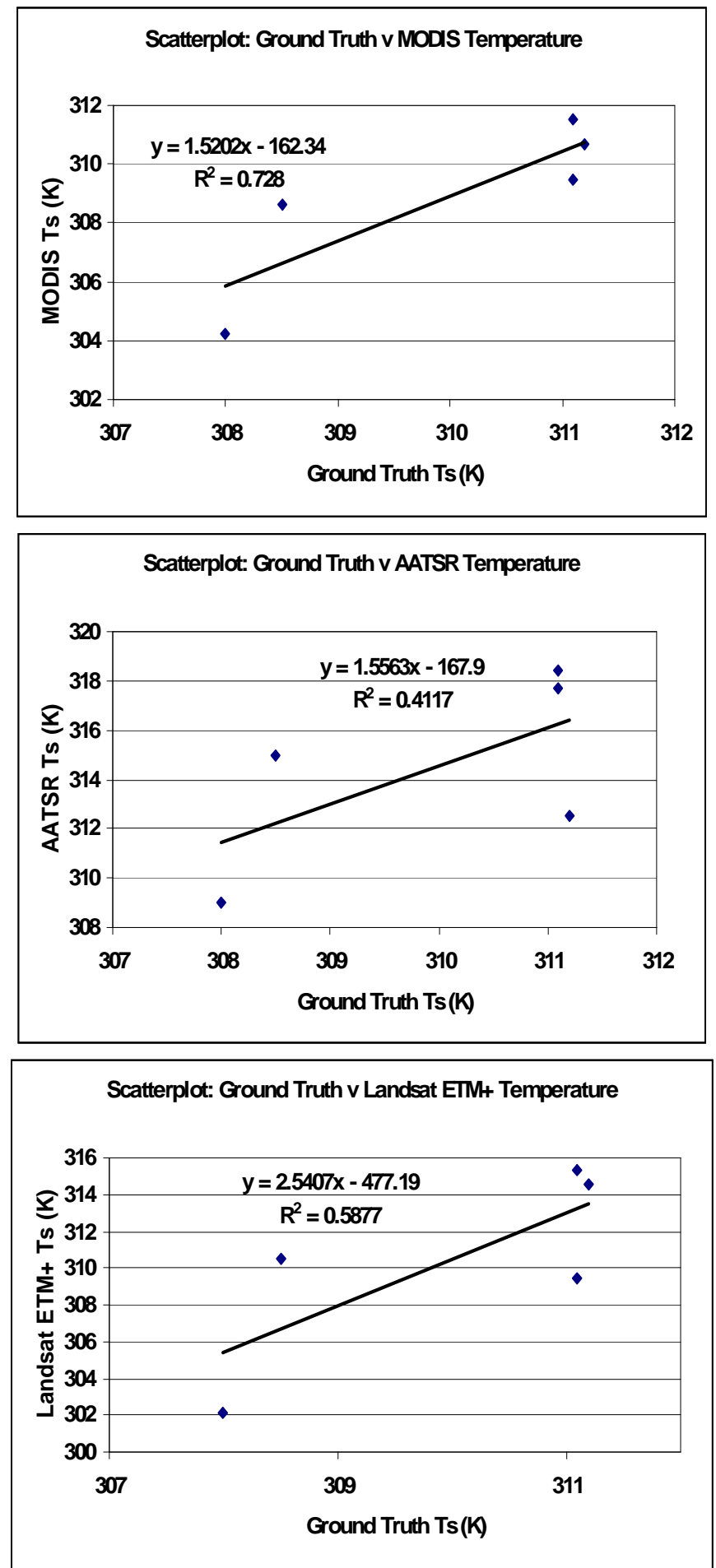
Figure 5. Regression models between NDVI and surface temperature $\left(T_{s}\right)$. The models are derived from full MODIS $(N=5486$ pixels $)$ and AATSR $(N=4139$ pixels $)$ scenes, (a) $\mathrm{T}_{\mathrm{s}}=-11.303 \mathrm{NDVI}+315.61 ; R^{2}=0.7458 ; \mathrm{RMSE}=0.051 ;$ and $(\mathrm{b}) \mathrm{T}_{\mathrm{s}}=-$ 18.655NDVI + 323.29; $R^{2}=0.6162 ; \mathrm{RMSE}=0.04993$.
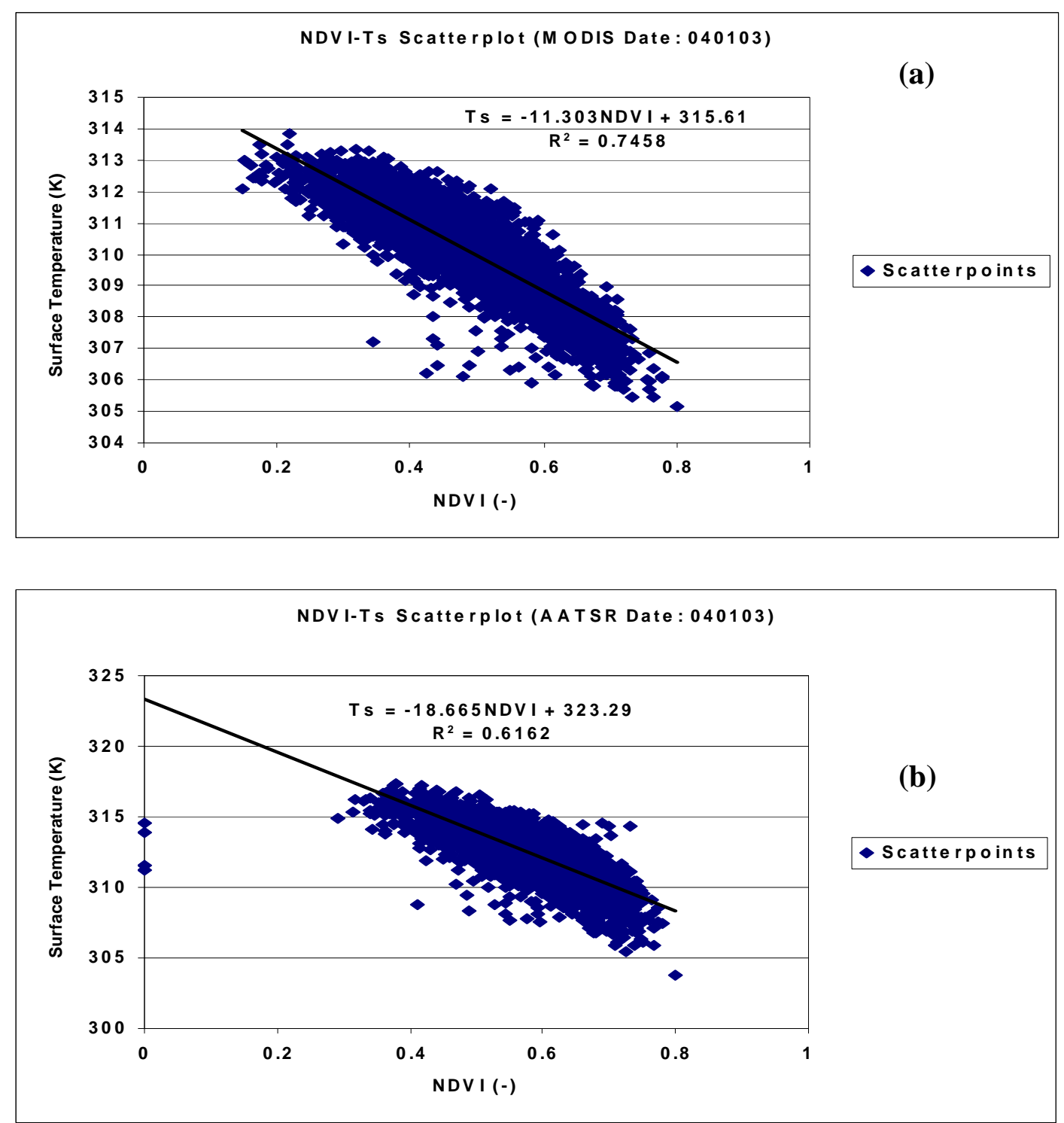

\section{Sensor Intercomparison of ET}

The importance of ET as a key indicator of water availability in dry savannah regions has previously been noted. In fact, the over- or underestimation of ET can provide misleading information required for water policy decision-making and resource allocation. Also, the question of data accuracy is an important issue because precise data sets are needed for continuous monitoring of ET, which in turn is needed for quantifying regional water balance. Both Table 6 and Fig 6 compare the temporal variability of ET measured from the MODIS and AATSR sensors. These are further compared with a detailed (30m resolution) Landsat ETM+ data acquired 4-5 weeks later. A detailed discussion follows here. 
Figure 6. Distributed ET (mm day ${ }^{-1}$ ) predicted from (a) MODIS, (b) AATSR and (c) Landsat ETM sensors on 131104, 121204 \& 05/01/04 respectively. Notice the spatial resemblance of both the MODIS and AATSR with Landsat ETM+, but the Landsat data better estimates ET because of its high spatial resolution $(30 \mathrm{~m})$. At least two Landsat scenes were required as a mosaic to cover the study area; lack of exact mosaic scenes presents an important limitation in regional synthesis. The blank spaces in (b) represent missing data, which rendered the November image unsuitable here. In this example, notice the similarity of the spatial relationship between ET and dense vegetation in the southern part of the image and sparsely vegetated Tamale urban area in the northwestern part.

Daily ET (MODIS Date:131104)
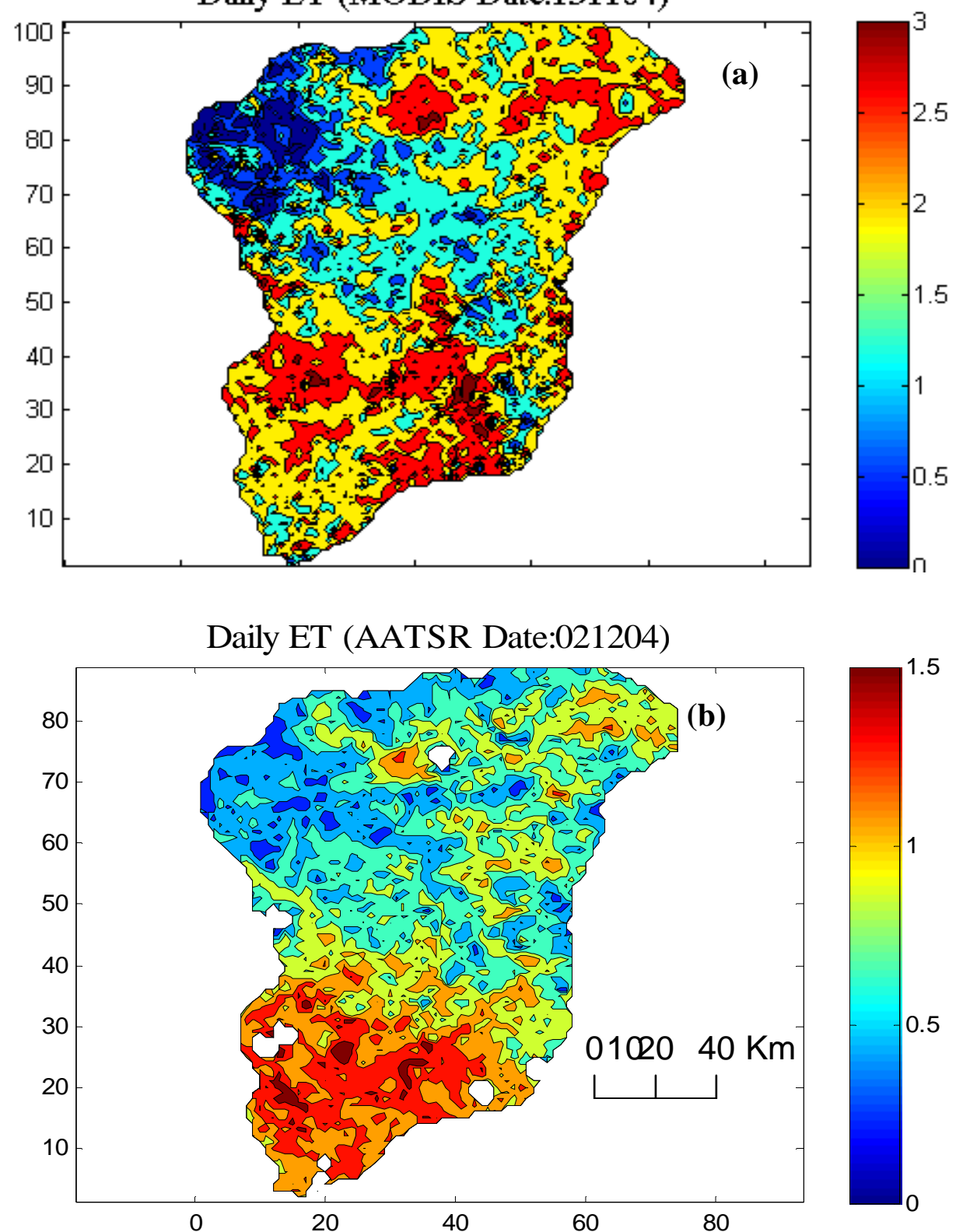
Figure 6. cont.

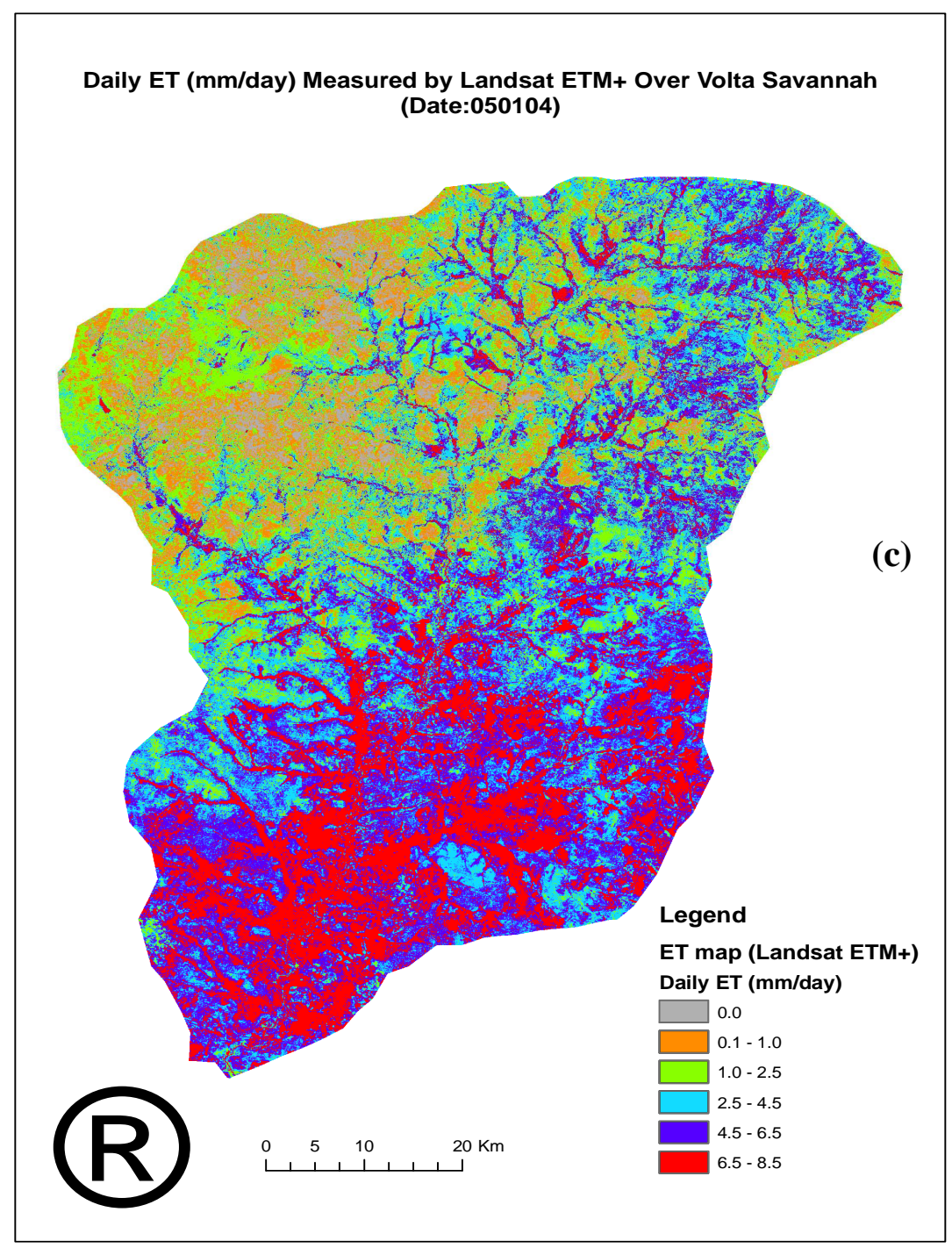

\subsection{Discussion}

Consideration of Table 6 shows that the average range of $\mathrm{T}_{\mathrm{s}}$ measured over the Tamale district by the MODIS sensor was 309.4 - $310.4 \mathrm{~K}$ compared with 317.0 - 323.1 $\mathrm{K}$ by the AATSR sensor. This is consistent with the sensor brightness temperatures shown in Table 7, which shows that $\mathrm{T}_{\mathrm{s}}$ measurements by the AATSR sensor are potentially higher $\mathrm{T}_{\mathrm{s}}$ than the MODIS instrument; additional evidence is shown in Fig 5. Here, the MODIS sensor produced a much better prediction of $\mathrm{T}_{\mathrm{S}}\left(R^{2}=\right.$ 0.73 ) than AATSR instrument $\left(R^{2}=0.41\right)$. A simple error analysis (i.e. calculation of the mean sensor deviations from the observed values) shows that the MODIS instrument underestimated ground temperatures by about $1.2 \mathrm{~K}$. By contrast, the AATSR overestimated surface temperatures by $4.1 \mathrm{~K}$. The difference between the sensor measurements may be due to their respective engineering design, sensor calibration and the satellite overpass time gap ( 60 minutes). It must be noted, however, that the above variation is consistent with the sensor design efficiency of both satellites and other published results. For example, comparing $\mathrm{T}_{\mathrm{s}}$ measurements from the MODIS and NOAA-14 AVHRR sensors, a 
difference of $25 \mathrm{~K}$ was observed within the overpass gap of $2-3$ hours of the two satellites [5]. In this case, output variations were attributed to a number of technical factors such as sensor characteristics, atmospheric correction and the spectral response function of the thermal infrared channels [5, 29]. In this study, differences between satellite and ground temperatures are important because the characteristics of "passive" thermal sensors make measurement of "skin" temperatures of bare soils difficult in the presence of other materials such as vegetation and water. In view of this, the results in Table 6 and Fig 4 represent soil surface temperatures as against radiant temperature measured by the sensors. Theoretically, these two measurements are quite different but are often compared for the sake of practicality [31]. Aside from this, differences between radiant and "skin" temperatures may not be unexpected over heterogeneous landscapes [30, 31]. Indeed, the infrared channels of MODIS and AATSR can be considered well suited for surface temperature measurement, but only to the degree of their design efficiency, which is rarely better than $3 \mathrm{~K}$ [32]. It can be concluded, therefore, that the MODIS and AATSR sensors have quite similar capabilities for measuring $\mathrm{T}_{\mathrm{s}}$ over complex savannah landscapes. An important question is why is there a relatively weak correlation between the Landsat ETM+ and the ground truth (logger) data $\left(R^{2}=0.59\right)$. The differences in the local environment at the time of Landsat overpass may account for this. For example, whereas the logger and MODIS and AATSR sensor measurements were made on the same day $\left(2^{\text {nd }}\right.$ December 2004), the Landsat temperatures were measured nearly 4 weeks later $\left(5^{\text {th }}\right.$ January 2005$)$. As noted earlier on, the Landsat ETM+ data was used mainly because of the absence of cloud-free alternatives for December 2004.

Both Table 6 and Fig 5 show that the AATSR sensor generally measures a narrower range of NDVI values, which may be due to the sensor's narrower bandwidth (see Table 4). Table 4 also confirms that the red $(R)$ and near infrared (NIR) bands of MODIS are more clearly separated than those of AATSR. For example, the width of the MODIS $R$ band is $0.50 \mu \mathrm{m}$, while that of AATSR is $20 \mu \mathrm{m}$. Still, AATSR has a narrower bandwidth in the NIR range. Previous studies have shown that broader reflectance bandwidths are correlated with spectral sensitivity of green vegetation [5, 33]. Also, the percentage of incident energy reflected by vegetation is a function of wavelength [30], which also explains why vegetation reflectance increases significantly over the NIR region; the wider the NIR region, the more variable vegetation discrimination can be over large areas. It should be noted, however, that the primary purpose of the AATSR sensor (unlike MODIS) is measurement of global sea surface temperature [7] which means, the optical range of the AATSR sensor has not been as fully calibrated and widely validated on land as MODIS [5]. The conclusion here is that although MODIS and AATSR may both derive reasonable $\mathrm{T}_{\mathrm{s}}$ measurements over vegetated surfaces, their NDVI products are not equivalent because of the wavelength positions of the appropriate reflectance bands, sensor and inter-calibration, and atmospheric correction. In this case, the AATSR may not be as suitable as MODIS for hydrological applications. However, the AATSR is a good sensor and so it should be possible to derive high quality products for hydrology with better calibration over land targets. 
Figure 7. Regression models between ETM+ET and (a) MODIS; $\mathrm{y}=1.0457 \mathrm{x} ; R^{2}=$ 0.7071 ; RMSE $=0.3359$; and (b) AATSR: $\mathrm{y}=1.0026 \mathrm{x} ; R^{2}=0.1262 ; \mathrm{RMSE}=0.6211$. Note: $N=71$ pixels because analysis covered the Tamale district where it was possible to cross validate with ground truth data.
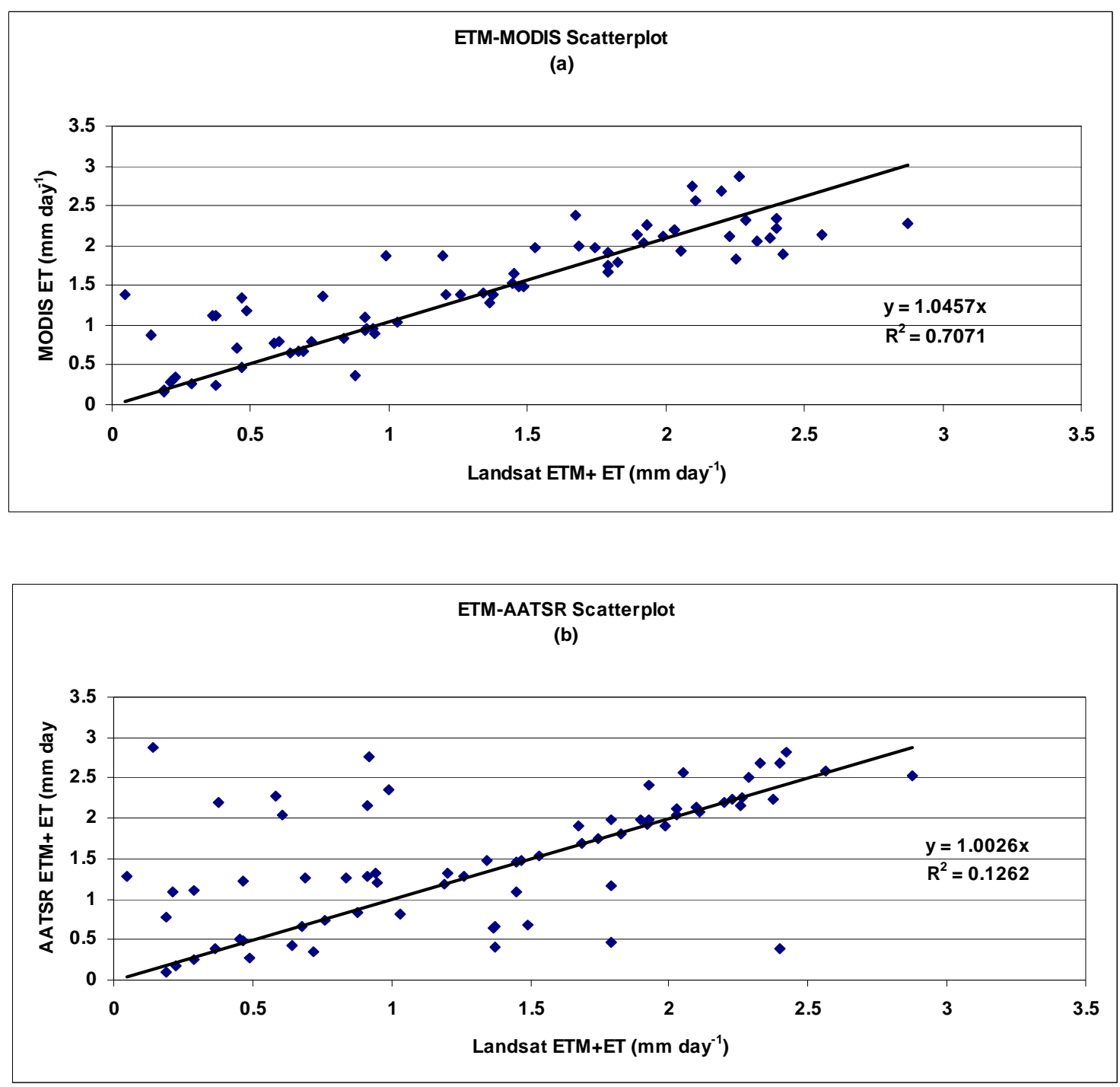

From Table 6, the AATSR sensor underestimates ET by about $32 \%$ in comparison with the MODIS sensor. Since data from both sensors have received the same modelling treatments, a plausible explanation is aggregated errors from key intermediate variables related with the ET model namely, $\mathrm{T}_{\mathrm{s}}$, NDVI and net radiation $\left(\mathrm{R}_{\mathrm{n}}\right)$. Whereas the MODIS instrument estimates a regional ET value of approximately $1.48 \mathrm{~mm} \mathrm{day}^{-1}$, the AATSR sensor measures only $0.47 \mathrm{~mm}$ day $^{-1}$. Thus, for one AATSR pixel $(1 \times 1 \mathrm{~km})$, the cumulative difference in water loss is approximately $2.45^{*} 10^{6} \mathrm{MJ} \mathrm{km}^{-2}$ day; assuming that $1.0 \mathrm{~mm} \mathrm{day}^{-1}$ evaporation is equivalent to $2.45 \mathrm{MJ} \mathrm{m}^{-2}$ day $^{-1}$. Over very large areas, a large amount of moisture loss could be underestimated. To better understand sensor differences, a quantitative evaluation is pursued using calculated values from the Penman-Monteith method, ground (eddy correlation) observations and Landsat ETM+ spatial measurements as validation sources. The range of estimated ET values for the Tamale district based on the Penman-Monteith method (in 2004) 
was $2.5-2.8 \mathrm{~mm} \mathrm{day}^{-1}[18]$. While agreeing that sensor validation based on point data is not always convenient, it still provides a good source of comparison in the absence of extensive field campaigns [29]. Based on the geographical extent of (x-y coordinates) of the Tamale area, a linear interpolation model was derived covering an approximate area of $70 \mathrm{~km}^{2}$. The mean ET value for Tamale, georeferenced from MODIS and AATSR ET maps was then compared. Here, both sensors underestimated regional ET by an average of $2.0 \mathrm{~mm} \mathrm{day}^{-1}$; the difference was probably related to the sensor footprints being too wide.

Energy flux (eddy correlation) observations (see Fig 2) were used as an additional basis for comparison in the absence of spatially observed ET estimates. In this case, diurnal latent heat for December 2001 (i.e. $50.87 \mathrm{~W} \mathrm{~m}^{-2}$ ) was converted as $1.79 \mathrm{~mm} \mathrm{day}^{-1}$, but again, both sensors underestimated ET by about $1.29 \mathrm{~mm} \mathrm{day}^{-1}$. As a final step, ET estimates from MODIS and AATSR were correlated with high resolution (30m) Landsat ETM+ data (Fig 7).

Fig 7a reveals a closer agreement between Landsat ETM+ and MODIS than AATSR (Fig 7b) where sensor correlation discrepancy could be as large as $0.6 \mathrm{~mm}$ day $^{-1}$. This strongly suggests that the AATSR errors may have aggregated from the measurement of the model intermediate parameters. Why this happens may also be related to problems in sensor calibration for land targets, atmospheric correction and/or poorly derived coefficients for the NDVI algorithm. Table 8 compares satellite-based ET with other methods.

Table 8. Satellite-based ET $\left(\mathrm{mm} \mathrm{day}^{-1}\right)$ vs. conventional methods in the Tamale Volta district.

\begin{tabular}{|l|l|l|l|l|}
\hline Method & Scale & Range & Mean & Standard deviation \\
\hline Penman-Monteith & Local (Tamale) & $1.53-4.87$ & 3.90 & 0.66 \\
\hline Scintillometer & Local (Tamale) & - & 1.79 & - \\
\hline Landsat ETM+ & Regional & $0.15-2.93$ & 2.10 & 0.42 \\
\hline MODIS & Regional & $0.05-2.83$ & 2.07 & 0.37 \\
\hline AATSR & Regional & $0.01-2.09$ & 1.21 & 0.86 \\
\hline
\end{tabular}

Careful consideration of Tables 6 to 8 and Figures 4 to 7 shows that both the MODIS and AATSR sensors have good potential for measuring energy fluxes over very large areas but are not as useful as Landsat over smaller areas. Also, AATSR appears to underestimate ET, which means for hydrological applications users have to apply this product with caution; further calibration of the (AATSR) reflectance bands may be necessary to derive accurate vegetation parameters.

\section{Conclusion}

This paper evaluated the potential of both MODIS and AATSR sensors for measuring regional-scale evapotranspiration (ET), based on the regional energy balance equation and driven by the SEBAL algorithm. The results show that both MODIS and AATSR can derive reasonable estimates of key variables such as NDVI (surrogate for biomass density), surface temperature $\left(T_{\mathrm{s}}\right)$ and ET over large vegetated savannah landscapes. The MODIS sensor measured daily NDVI, $\mathrm{T}_{\mathrm{s}}$ and ET much better 
than its AATSR counterpart. For example, a high spatial correlation was found between MODIS and thermal logger data $\left(R^{2}=0.73\right)$ in comparison with $\left(R^{2}=0.41\right)$ by the AATSR sensor. In terms of ET, a similar correlation $\left(R^{2}=0.71\right)$ was found between the MODIS and Landsat ETM+ sensors as against $R^{2}=0.13$ by the AATSR sensor. When the MODIS and AATSR sensors were evaluated against point observations of ET such as eddy correlation observations and the Penman-Monteith method, they both underperformed ( 2.0 $\left.\mathrm{mm}_{\text {day }}{ }^{-1}\right)$ mainly because of scale mismatch. It must be noted that the AATSR sensor performed poorly against the MODIS, Landsat ETM+ and ground data, mainly because of differences in the spectral bands, sensor calibration and atmospheric correction. This will require further investigation if an improved land-calibrated AATSR product becomes available. Indeed, the AATSR was primarily designed for ocean rather than land-based studies. Therefore, for hydrological applications, the MODIS data is preferred at the present time.

\section{Acknowledgements}

We wish to sincerely thank ESA for supplying ENVISAT-AATSR data through the ESA/UNESCO Volta TIGER Project \#2992 and NASA for providing free access to MODIS L1B data. The research fellowship provided by the Government of Ghana for the principal author to complete his Ph.D. at Durham University (UK) is also greatly appreciated. Finally, we gratefully acknowledge the helpful comments of the anonymous referees.

\section{References}

1. Washington, R.; Harrison, M.; Conway, D.; Black, E.; Challinor, A.; Grimes, D.; Jones, R.; Morse, A., Kay, G.; Todd, M. African climate change: Taking the shorter route. BAMS 2006, 10, 1355-1365.

2. Gyau-Boakye, P.; Timbulto, J.W. The Volta Lake and declining rainfall and streamflows in the Volta river basin. Environ. Dev. Sustainability 2000, 2, 1-10.

3. Oguntunde, P.G. Evapotranspiration and complimentary relations in the water balance of the Volta basin: Field measurements and GIS-based regional estimates. In Ecology and Development Series, Denich, M., Martius, C., van de Giesen, N. Eds.: Cuvillier Verlag, Göttingen, 2004, pp103-155.

4. Bisht, G.; Venturini, V.; Jiang, L.; Islam, S. Estimation of the net radiation using MODIS data for clear-sky dates. Rem. Sens. Environ. 2005, 97, 52-97.

5. Brata, N.; Islam, S.; Venturini, V; Bisht, G.; Jiang, L. Estimation and comparison of evapotranspiration from MODIS and AVHRR sensors for clear sky days over the Southern Great Plains. Rem. Sens. Environ. 2006, 103, 1-15.

6. Parks, S.; Feddema, J.J; Egbert, S.L. MODIS land surface temperature composite data their relationships with climate water budget factors in the Central Great Plains. Int. J. Rem. Sens. 2005, 26 (6), 1127-1144.

7. Prata, F. Land surface temperature measurement from space: AATSR algorithm - Theoretical basis document. Technical Report: 2002, CSIRO, Canberra, Australia, pp 1-34.

8. Sòria, G; Sobrino, J.A. AATSR derived land surface temperature from heterogeneous areas, Proc. ESA's ENVISAT MERIS-AATSR workshop 2005, Frascati, Italy, pp 1-6. http://envisat.esa.int 
9. Jiang, L.; Islam, S. An intercomparison of regional heat flux estimation using remote sensing data. Int. J. Rem. Sens. 2003, 24(11), 2221-2236.

10. Günther, K.P.; Maier, S.W. AVHRR compatible vegetation index derived from MERIS data. Int. J. Rem. Sens. 2007, 28(3-4), 693-708.

11. ZEF (Centre for Development Research) Ecology and Development Series: GLOWA-Volta Project, 1999-2005, Cuvelier Verlag, Göttingen, 2004: pp 1-138.

12. Nicholson, S.E.; Grist, J.P. A conceptual model for understanding rainfall variability in the West African Sahel interannual and interdecadal timescales. Int. J. Climatol. 2001, 21, 1733-1757.

13. Ayibotele, N.B. Regional hydrology and water resources in the African humid tropics. In Hydrology and water management in the humid tropics. Bonnel, M., Hufschmidt, M. M.,Gladwell, J. S. Eds.; University Press: Cambridge, 1993; pp 112-134.

14. Ghana Meteorological Services Department (MSD) Daily rainfall and temperature records over the Volta basin in Ghana, 1961-2000, July 2004 pp. 22-134.

15. Prince, S.D.; Kerr, Y.H.; Goutorbe, T.; Lebel, J-P; Tinga, A.; Bessemoulin, P.; Brouwer, J.; Dolman, A.J.; Engman, E.T.; Gash, J.C.H. Geographical, biological and remote sensing aspects of the Hydrological Atmospheric Pilot Experiment in the Sahel (HAPEX-Sahel). Rem. Sens. Environ. 1995, 51, 215-234.

16. MODIS Characterization Support Team (MCST) MODIS LUT Information Guide For Level 1B, MCST Internal Memorandum \# M1036, December 1, 2003. The latest release is available on-line at http://www.mcst.ssai.biz/mcstweb/L1B/product.html

17. Wan, Z. MODIS land surface temperature validation. The Earth Obs. 1999, 11(3), 29-31.

18. Opoku-Duah, S. Remote Sensing of Energy and Water Fluxes over Volta Savannah Catchments in West Africa, Unpublished Ph.D. Thesis: 2007, Durham University, UK, pp 123-222.

19. Donoghue, D.N.M. Remote Sensing: sensors and applications. Prog. Phys. Geogr. 2000, 24(3), 407-414.

20. Price, J.C. Land surface temperature measurements from split window channels of the NOAA-7 Advanced Very High Resolution Radiometer. J. Geophys. Res. 1984, D5(89), 7231-7237.

21. Goetz, S.J. Multi-sensor analysis of NDVI, surface temperature and biophysical variables at a mixed grassland site. Int. J. Rem. Sens. 1987, 18 (1), 71-94.

22. Bastiannssen, W.G.M.; Menenti, M.; Feddes, R.A.; Holtslag, A.A.M. A remote sensing surface energy balance algorithm for land (SEBAL) - Part 1: Formulation. J. Hydrol. 1998, 228, 198-212.

23. Bastiaanssen, W.G.M.; Pelgrum, H.; Wang, J.; Ma, J.; Moreno, J.; Roerink, G.J.; Van Der Wal, T. (1998) The Surface Energy Balance Algorithm for Land (SEBAL): Part 2 validation. J. Hydrol. 1998, 228, 213-229.

24. Morse, A.; Tasumi, M.; Allen, R.G.; Kramber, W.J. Application of the SEBAL Methodology for Estimating Consumptive Use of Water and Streamflow Depletion in the Bear River Basin of Idaho through Remote Sensing, Final Project Report: 2000, The Raytheon Systems Company, Idaho, USA, pp 1-107.

25. FAO, Evapotranspiration Guidelines for computing crop water requirements - UN-FAO, Irrigation \& Drainage Paper No. 56, Land and Water Division, FAO Press, Rome, 1998, pp 107288. 
26. Chen, T.S.; Ohring, G. On the relationship between clear-sky planetary and surface albedos: a parameterization for simple energy balance climate models. Adv. Space Res. 1985, 5(6), 41-144.

27. Mekonnen, S.C. Assessment of catchment water balance using GIS and Remote Sensing: Roxo, Portugal, Unpublished MSc. Thesis: 2005, ITC-Enschede, The Netherlands, pp 1-39.

28. van de Griend, A.A.; Owe, M. On the relationship between thermal emissivity and the normalized difference vegetation index for natural surfaces. Int. J. Rem. Sens. 1993, 14(6), 1119-1131.

29. Prata, F. Land surface temperatures derived from the Advanced Very High Resolution Radiometer and the Along-Track Scanning Radiometer. J. Geophys. Res. 1994, 99, 13-25.

30. Sellers, P.J. Canopy reflectance, photosynthesis and transpiration. Int. J. Rem. Sens. 1985, 6(8), 1335-1372.

31. Sobrino, J.A.; Jiménez-Muńoz, J.C. Land surface temperature retrieval from thermal infrared data: An assessment in the context of the surface processes and ecosystem changes through response analysis (SPECTRA) mission. J. Geophy. Res. 2005, 110, D16103, doi: 1029/2004JD005588.

32. Salomonson, V.V.; Barnes, W. L.; Xiong, X.; Kempler, S.; Masuoka, E. An Overview of the Earth Observing System MODIS Instrument and Associated Data Systems Performance, In Proceedings of IGARSS, Barnes, T.G., Ed..; Chicago, 2002; p 23-31.

33. El Maayar, M.; Chen, J.M. Spatial scaling of evapotranspiration as affected by heterogeneities in vegetation, topography and soil texture. Rem. Sens. Environ. 2006, 102, 33-51.

(C) 2008 by MDPI (http://www.mdpi.org). Reproduction is permitted for noncommercial purposes. 